\title{
JUAN DE SOLÓRZANO PEREIRA Y LA DEFENSA DEL INDIO EN AMÉRICA
}

\author{
POR \\ CARlos BACIERO \\ Colaborador en la Colección Corpus Hispanorum de Pace de CSIC, Madrid
}

\section{RESUMEN}

La inmensa erudición jurídica, filosófica y teológica de Juan Solórzano Pereira y el exhaustivo conocimiento de la legislación de Indias hacen de él una figura de primera magnitud en el campo del derecho indiano en el siglo XVII. Ello explica el mandato real que Felipe III le impuso, al ser enviado al Virreinato de Perú como Oidor de la Audiencia de Lima, de recoger y publicar las cuestiones fundamentales referentes al derecho indiano, que redujo a tres: 1. Justicia de la ocupación de las Indias por los españoles; 2. Justicia de la permanencia española en las Indias; 3. Justicia de la Administración y Gobernación españolas en las Indias.

PALABRAS CLAVE: legislación de Indias, Juan Solórzano, Felipe III. Virreinato de Perú, Audiencia de Lima, siglo XVII

\section{ABSTRACT}

Juan Solórzano Pereira was outstanding in 17th century Spain both for his vast erudition in Philosophy, Theology and Law and for his thorough knowledge of legislation concerning the American colonies. It was quite natural for Philip III to send him to Peru as Oidor of the Lima Tribunal and give him the mandate to compile and publish the materials dealing with the most fundamental problems of colonial legislation. He did so in three steps: 1.The question of justifying the Spanish takeover. 2. The rightfulness of continuing the Spanish presence in those territories. 3. The critical appraisal of the Spanish Administration and Government in the area.

KEY WORDS: Legislation concerning the American colonies, Juan Solórzano, Peru, Lima, 17th century 
En carta de 8 de abril de 1618 a Felipe III Juan Solórzano y Pereira da cuenta de la obra que está escribiendo - se refería a su tratado De indiarum iureen los escasos tiempos que le dejan libre sus ocupaciones como oidor de la $\mathrm{Au}-$ diencia de Lima y las múltiples consultas que le llegan como a eminente experto en cuestiones jurídicas sobre los diversos problemas de la sociedad indiana. En esta obra — escribe Solórzano al rey- «se juntan y tratan todos los puntos dignos de consideración que se suelen y pueden ofrecer en las materias del gobierno y justicia de estas Indias Occidentales».

En realidad estaba cumpliendo un mandato real. Como él mismo recuerda en la Dedicatoria a Felipe IV de su Política indiana, el Rey Felipe III le había ordenado, al ser enviado al virreinato del Perú, «que atendiese y escribiese todo lo que juzgase concerniente y conveniente a su derecho y gobierno». La orden quedó cumplida y Solórzano se puede permitir ahora hablar al rey del gran trabajo puesto «en juntar, disponer e ilustrar tan varias materias, en que me atrevo a afirmar sin jactancia que soy... el primero que las he escrito sin poner planta sobre huella ajena».

La amplitud y novedad, efectivamente, de los temas abordados con pretensiones de totalidad se desbordó por las 1.300 apretadas páginas de texto a doble columna en dos volúmenes de gran tamaño. El volumen primero presenta el siguiente título: De Indiarum iure sive de iusta Indiarum Occidentalium inquisitione, acquisitione et retentione. Su materia queda, pues, dividida en tres grandes cuestiones tratadas en sendos libros: descubrimiento, conquista y retención de las Indias. El volumen segundo lleva por título De Indiarum iure sive de iusta Indiarum occidentalium gubernatione, y comprende cinco libros en los que se estudian y se someten a revisión las principales instituciones que estructuran el funcionamiento de la sociedad indiana de entonces: encomiendas, sistema tributario, servicios personales, sistema educativo...

La buena acogida que tuvo la obra y los deseos de numerosas personas que le pedían por carta la traducción al castellano movieron a Solórzano a publicar la Política indiana, que resultó ser una especie de adaptación o vulgarización, menos especializada científicamente, de la obra latina, que queda en parte resumida y en parte enriquecida con nuevos datos, como él mismo nos dice. Concretamente los títulos justificativos de la conquista y permanencia de España en Indias, que en el volumen primero del De Indiarum iure ocupaban íntegramente los libros II y III, en la Política indiana quedan enormemente simplificados y reducidos a los capítulos 9-12 del libro I.

Estas dos obras son un claro exponente de los vastísimos conocimientos jurídicos que poseía (sobre todo en lo referente a los problemas indianos), así como de su prudencia, de su integridad y de su sentido estricto de la justicia en todas sus actuaciones. A este respecto nos dejó él mismo constancia escrita de

Hispania Sacra, Missionalia hispanica, 58

117, enero-junio 2006, 263-327, ISSN: 0018-215-X 
algunas decisiones judiciales, un tanto comprometidas y valientes, que por razones de oficio hubo de tomar. Así nos recuerda el castigo que, siendo fiscal en el Supremo Consejo de Indias, impuso al heredero de un tal Hernando Vera, antiguo encomendero, a quien, «por los demasiados tributos que cobró de sus indios y otros graves daños y vejaciones que se probó haberles hecho, le privaron de ellos y fue condenado a una gran suma de ducados, para cuya paga se le vendieron en almoneda todos los bienes que tenía, y entre ellos el pueblo de San Martín de Valdeiglesias, que había comprado en España» ${ }^{1}$.

Sorprende también la gran erudición y el enorme volumen de lecturas que se reflejan en las páginas de sus obras: lecturas jurídico-canónicas, históricas, filosófico-teológicas e incluso literarias. Demuestra además Solórzano un exhaustivo conocimiento de toda la legislación de Indias desde sus orígenes hasta el momento en que está redactando la obra. Bien es verdad que no todos los autores $\mathrm{u}$ obras de autores que cita pueden ser considerados como fuentes directamente consultadas por él. Es obvio pensar que una buena parte de estas citas son meramente indirectas, que transcribe — sin más mirar y, por tanto, con los mismos eventuales errores - de los autores directamente consultados. Sin embargo, no es infrecuente el caso en que advierte expresamente que no ha podido llegar a tal o cual obra de determinado autor, a pesar de haberla buscado.

Muestra además seria preocupación por estar al corriente de las últimas publicaciones, hasta el punto de que con frecuencia utiliza expresiones como «se acaba de publicar recientemente...» $\mathrm{o}$ «después de escrito esto, ha aparecido...». Pero hay que reconocer también que esa especie de pasión por la cita llega a veces a enturbiar en cierto grado el contenido y a hacer un tanto fatigosa la lectura.

Respecto a las fuentes filosóficos-teológicas se ha de decir que, además de los autores clásicos de la antigüedad greco-latina, de la Patrística latina y griega y de la alta Edad Media (a quienes de ordinario cita por simple compromiso de erudición), los que verdaderamente modelan el pensamiento de Solórzano e influyen de modo decisivo sobre él son los maestros de la Escuela de Salamanca, entendida ésta en un sentido de cierta amplitud. De entre ellos pueden considerarse como los citados (muchas veces con elogio) Juan Azor, Domingo Báñez, Alfonso de Castro, Antonio de Córdoba, Serafín Freitas, Pedro de Ledesma, Bartolomé de Medina, Luis de Molina, Juan de Salas. Domingo de Soto, Francisco Suárez, Gregorio de Valencia, Gabriel Vázquez...

Pero podemos afirmar que son Francisco de Vitoria y José de Acosta los que sin duda ejercen sobre él un influjo más directo y decisivo en todas las cuestiones filosófico-teológicas de alguna importancia estrictamente relacionadas con la problemática indiana y es a ellos a quienes reserva los más encendidos elo-

\footnotetext{
1 Juan SolóRzano, Política indiana, lib. III, cap. 26, n. 31 (Biblioteca de Autores Españoles 252, 307).
} 
gios. Llama a Vitoria «astro el más refulgente de la Orden Dominicana». Respecto de Acosta es frecuente la repetición de frases elogiosas a su nombre, citado innumerables veces; en él se apoya constantemente.

La profunda huella que dejó Acosta, sobre todo en el virreinato del Perú, y la fama de su prestigiosa personalidad estaban todavía muy vivas por aquellos en que Solórzano ejercía su oficio de Oidor de la Real Audiencia de Lima. Considera sus escritos «doctísimos y elegantísimos»; otras veces hablará del «elegantísimo Padre José de Acosta», o de su «habitual prudencia», o de sus «graves palabras y sólidas razones»; o cuando después de citar a otros autores concluye con la mayor naturalidad: «Y mejor que todos el Padre José de Acosta ${ }^{2}$.

Solórzano aduce y transcribe textos íntegros de Vitoria y Acosta, bien sea en apoyo de su tesis (el caso más frecuente), o bien sea, por el contrario, para mostrar su desacuerdo. Cuando esto último ocurre y en la medida en que ocurre, se da en él una aproximación a la línea de pensamiento representada por Juan Ginés de Sepúlveda. Es el peso de su compromiso en defender ante Europa a la Corona española lo que, posiblemente, le fuerza a ese calculado y parcial distanciamiento del común sentir de la Escuela en determinadas cuestiones. Ello no obsta para concluir con toda legitimidad, a mi juicio, que es dentro del horizonte y del espíritu de la Escuela de Salamanca donde él se sitúa y desenvuelve normalmente sus reflexiones. Su sentido de equilibrio y de justicia, su afán de veracidad y objetividad dentro de la meta que se había propuesto y las conclusiones a que llega en la mayor parte de las cuestiones importantes acreditan su pertenencia a la Escuela de Salamanca. Lo pone de manifiesto la fundamentación filosófico-teológica sobre la que Solórzano monta su defensa de España ante las acusaciones («calumnias» las llama él) de la Europa protestante.

La obra de España en América, en cuya defensa empeña Solórzano su prestigio personal y su saber, abarca estas tres grandes y fundamentales cuestiones: Justicia de la ocupación de las Indias por los españoles, Justicia de la permanencia de España en las Indias, y Justicia de la Administración y Gobernación españolas en las Indias. Con esto queda trazado el camino que vamos a recorrer.

\section{JUSTICIA DE LA OCUPACIÓN ESPAÑOLA}

\section{Título primero: la voluntad}

A imitación de Vitoria examina aquellos títulos que pueden de Dios aducirse para justificar la ocupación española de las Indias. El primero de ellos es un tí-

2 O. c., lib. II, cap. 6, n. 2 (BAE 252, 170).

Hispania Sacra, Missionalia hispanica, 58

117, enero-junio 2006, 263-327, ISSN: 0018-215-X 
tulo providencialista, cuyo valor no pone en duda: la voluntad de Dios que dirige el curso de la historia y distribuye los reinos. Dios ha querido reservar a los reyes de España el descubrimiento del Nuevo Mundo y concederles sus reinos para llevar a aquellos pueblos a la luz de la fe.

\section{Título segundo: la inspiración divina}

Un segundo título es la inspiración e impulso divino que movió a los reyes de España y sus vasallos al descubrimiento y conquista del Nuevo Mundo. Ve la existencia de dicha inspiración en múltiples acontecimientos históricos que se recogen tanto en la Sagrada Escritura como en las crónicas de la Historia Eclesiástica; da abundantes nombres de autores que aceptan este hecho en general, y los de otros autores que lo reconocen concretamente en el caso presente. Y cree ver los «signos» de esta inspiración divina en «la predicación de la palabra de Dios, el conocimiento de Jesucristo, la conversión de muchos pueblos, la salvación de muchísimas almas de niños, hombres, mujeres y hasta de enfermos que, clavados largo tiempo en el lecho, al fin recibiendo el bautismo volaron al cielo», los milagros que se sucedieron ${ }^{3}$. En efecto, «hubo y sigue habiendo hoy día numerosos milagros que prueban con evidencia la voluntad y casi diría el placer de Dios en esta gran empresa ${ }^{4}$. Reconoce, bien es verdad, que estos dos primeros títulos, aunque «eficacísimos» y «de peso», no constituyen una prueba evidente ${ }^{5}$.

\section{Título tercero: el descubrimiento}

Por eso propone un tercer título: el derecho del descubrimiento y ocupación. Se corresponde con el título tercero, no legítimo, de Vitoria. Solórzano reduce la validez del título a los siguientes límites: «Como en este inmenso y dilatado espacio de territorios que descubrieron y recorrieron los españoles con su esfuerzo y habilidad, había muchas zonas deshabitadas a las que los propios indios no habían llegado o las habían dejado desiertas y sin cultivar..., sin duda se ha de afirmar que al menos con relación a estas zonas el mencionado título es útil y legítimo» ${ }^{6}$. En realidad el derecho de ocupación así restringido no es título que justifique la ocupación de todos los territorios indianos; y aquí precisamente reside el problema. Solórzano, pues, no va más allá de lo que ya Vitoria

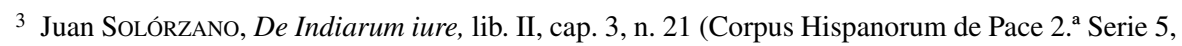
97).

4 O. c., lib. II, cap. 3, n. 47 (CHP 2.. Serie 5, 105).

5 O. c., lib. II, cap. 6, n. 1 (CHP 2. ${ }^{\text {a Serie } 5,181) .}$

6 O. c., lib. II, cap. 6, n. 81 (CHP 2.. Serie 5, 207).
} 
había reconocido al afirmar que «hay otros muchos bienes que ellos [los indios] dan por abandonados y son comunes a todos los que los quieran aprovechar» ${ }^{7}$.

\section{Título cuarto: estado de barbarie de los indios}

Solórzano examina un cuarto título (muy querido de Sepúlveda), que pudiera justificar la ocupación de las Indias: El estado de barbarie en que se encuentran los indios. Esta cuestión arrastra consigo preguntas de suma gravedad desde el punto de vista humano, político, social y religioso, que ya otros antes que él se habían planteado: ¿Son los indios verdaderos hombres? ¿Son esclavos por naturaleza? ¿Hasta dónde llega su estado de barbarie? ¿Su situación de incultura y salvajismo justifica una guerra de sometimiento?

¿Cuál fue la respuesta de Solórzano a estas tremendas preguntas? Vitoria había hablado ya de las claras manifestaciones de uso de razón que se observaban en los indios: tenían sus ciudades bien establecidas, sus matrimonios bien definidos, sus magistrados, señores, leyes, industrias, comercio y una forma de religión, «y todo ellos requiere uso de razón» ${ }^{8}$.Está convencido Solórzano, con el sentir común de la Escuela de Salamanca, de que la torpeza o rusticidad de los indios «no se debe tanto a su índole natural o temple nativo cuanto a una ya de antes mala educación... y a falta de instrucción» ${ }^{9}$. Desde este presupuesto no puede aceptar, a una con todos los maestros se la Escuela de Salamanca, la esclavitud natural de los indios entendida del modo riguroso de Aristóteles, que hace suyo Sepúlveda.

Es indudable que todos los indios son por naturaleza libres y dueños de sus bienes y que, por su incultura, no se les puede privar de su libertad y dominio ni subyugarlos por la fuerza o incluso cazarlos como a las fieras (como algunos pretende siguiendo a Aristóteles), para que aprendan a vivir bien. «Porque esto es falso y absurdo». Y aunque lo diga Aristóteles, «no por eso se han de tener en cuenta sus palabras, si son contrarias a las leyes y costumbres de la disciplina cristiana; puesto que, como pagano que era, está sepultado en el infierno, como duramente proclamó el obispo de Chiapa [Bartolomé de las Casas] ante Carlos $\mathrm{V} \gg{ }^{10}$. Y constata por propia experiencia que, en cumplimiento de las Leyes Nuevas y otras cédulas reales, en Lima se empezó a poner en libertad tanto a los indios occidentales como a los orientales que habían sido importados.

\footnotetext{
${ }^{7}$ Francisco DE Vitoria, Relectio de indis, I parte, cap. 3, n. 17 (Corpus Hispanorum de Pace=CHP $5,99)$.

${ }^{8}$ Francisco de Vitoria, Relectio de indis, I parte, cap. 1, n. 15 (CHP 5, 29).

9 Juan Solórzano, De Indiarum iure, lib. II, cap. 8, n. 87 (CHP 2. a Serie 5, 301).

10 O. c., lib. II, cap. 8, nn. 117-119, 122-124 (CHP 2. ' Serie 5, 109, 122); Política indiana, lib. II, cap. 1, n. 24 (BAE 252, 138).
}

Hispania Sacra, Missionalia hispanica, 58

117, enero-junio 2006, 263-327, ISSN: 0018-215-X 
Al igual que Acosta, Solórzano distingue tres clases de bárbaros. La primera es la de aquellos que no se apartan gran cosa de la recta razón y de la práctica del género humano; tienen una buena organización política, comercio próspero y letras; a ella pertenecen los chinos y japoneses. La segunda es de aquellos que tienen una organización política, con sus magistrados, jefes militares, normas de comportamiento y un cierto esplendor de culto religioso; pero no ha conocido escritura y están todavía muy lejos de la recta razón; a ella pertenecen los mexicanos y peruanos. En la tercera entran los hombres salvajes, semejantes a las fieras, que apenas tienen sentimientos humanos, nómadas y sin organización política; a ella pertenecen los caribes y antropófagos ${ }^{11}$.

De acuerdo con la doctrina de la Escuela de Salamanca Solórzano juzga necesario que los reyes de España ejerzan al menos sobre los indios agrupados en la segunda clase un supremo gobierno que los ponga en condiciones de recibir la luz del Evangelio y llevar una vida digna de hombres, pero respetando sus patrimonios y sus tradiciones que no sean contrarias a la naturaleza y al Evangelio. Gobierno que no ha de ser despótico, sino suave y orientado hacia la promoción humana de los indios, puesto que son libres por naturaleza ${ }^{12}$.

Por lo que respecta a los indios incluidos en la tercera clase su estado de barbarie constituye para Solórzano un título legítimo de conquista. Y precisamente porque la conversión de los indios es el fin primordial de la conquista, una vez alcanzada la victoria se les ha de dejar en su antigua y natural libertad, ejercer con ellos la clemencia y tratarles con amabilidad y comprensión, para atraerlos a la fe. Y esto implica un profundo respeto a la libertad, porque la libertad es un don inestimable que tiene preferencia sobre todas las cosas, hasta el punto de que muchas veces prevalece frente a reglas comunes del derecho, y su privación se compara a la muerte. A este respecto recuerda Solórzano el hondo sentimiento que ya los Reyes Católicos tuvieron ante la noticia de los trescientos esclavos traídos de la Isla Española y repartidos por Colón ${ }^{13}$.

\section{Título quinto: la infidelidad}

Solórzano pasa a considerar un título quinto de legitimidad, problemático y objeto de largas discusiones: ¿Se puede hacer la guerra y subyugar a los indios por su pecado de infidelidad, por su obstinación en recibir la fe? Es el cuarto de los títulos considerados por Vitoria como no legítimos. ¿Cuál es la opinión de Solórzano? Consciente de que está dando una respuesta a Europa no quiere de-

\footnotetext{
11 O. c., lib. II, cap. 9, nn. 1, 3, 9-12 (CHP 2. ${ }^{\text {a }}$ Serie 5, 321-323).

12 O. c., lib. II, cap. 9, nn. 19-21 (CHP 2. ${ }^{\text {a }}$ Serie 5, 327-329).

13 De Indiarum iure, lib. III, cap. 7, nn. 58-67 (CHP 2. ' Serie 1, 441-445); Política indiana, lib. II, cap. 1, n. 14 (BAE 252, 135).
} 
saprovechar la fuerza argumental que a este nuevo título pueda venirle de prestigiosos autores (y no precisamente españoles), de reconocida autoridad mundial, con el Ostiense a la cabeza. Tras exponer en torno a esta cuestión las diversas posturas y las razones que las fundamentan, añade: «En cuestión tan dudosa, corroborada por tantos y tan ponderados argumentos y autoridades de uno y otro lado, no ahorrará sacrificios quien pretenda la defensa de esta o de aquella opinión...» ${ }^{14}$. No obstante, terminará concediendo que, si los infieles no perturban la fe de los cristianos con quienes conviven, en ese caso «la opinión más verdadera y generalizada es que sólo por causa de su infidelidad no se puede de ordinario privar a los infieles de su dominio» ${ }^{15}$.

\section{Título sexto: los pecados contra la naturaleza}

El sexto título que Solórzano señala para justificar a la Corona española resulta de difícil aplicación, como tal título, por la complejidad de aspectos muy distintos que en él se acumulan y que parecen romper la unidad del concepto. Estos aspectos, englobados bajo el concepto de un mismo título, son los siguientes: que cometen los más abominables pecados contra la naturaleza, que ejercen la tiranía, que son antropófagos e idólatras, que ofrecen sacrificios humanos. Difícilmente se puede dar una respuesta unitaria que englobe indistintamente todos estos aspectos; cada uno de ellos de por sí parece constituir un título de distinto orden.

Vitoria en el título quinto de los por él considerados como no legítimos incluye solamente los pecados contra la naturaleza y llega a la siguiente conclusión: «Los príncipes cristianos, ni aun con la autorización del Papa, pueden apartar por la fuerza a los indios de los pecados contra la ley natural ni castigarlos por esta causa». Y esto cualquiera que sea el sentido que se dé al concepto de «pecado contra la naturaleza»; es decir, bien sea un sentido general o un sentido estricto y específico. Ningún pecado contra la naturaleza, en cuanto tal pecado, puede jamás justificar una guerra.

José de Acosta llegará a decir con punzante ironía que «difícilmente se han cometido jamás tantos y tan enormes crímenes por ningún pueblo bárbaro y fiero o escita como por esos defensores del derecho natural...» ${ }^{16}$. A la misma conclusión habían llegado casi todos los maestros de la segunda generación de la

\footnotetext{
14 De Indiarum iure, lib. II, cap. 22, n. 2 (CHP 2. ${ }^{a}$ Serie 5, 385).

15 O. c., lib. II, cap. 11, n. 58 (CHP 2. ${ }^{\text {a Serie } 5,405) .}$

16 Francisco DE VITORIA, Relectio de indis (CHP 5, 69-72); JosÉ DE ACOSTA, De procuranda indorum salute CHP 23, 281): Juan de la Peña formuló diáfanamente la tesis: «Ningún poder civil ni del rey por derecho natural puede castigar príncipes o repúblicas que no le están sometidas, por crímenes contra la ley natural o por razón de idolatrí» (CHP 9, 227).
}

Hispania Sacra, Missionalia hispanica, 58

117, enero-junio 2006, 263-327, ISSN: 0018-215-X 
Escuela, para quienes ni la infidelidad ni la idolatría ni ningún tipo de pecado contra la naturaleza pueden justificar una conquista de los indios. Porque no hay más justa de guerra que la injuria inferida, como repiten insistentemente. Es un principio general irrenunciable y de absoluta garantía.

¿Qué postura adopta Solórzano ante este problema? Queda, obviamente, impresionado ante la gravedad de tales abominables aberraciones, de las que, siguiendo a Acosta, traza el siguiente cuadro estremecedor: «Además de la idolatría, de los ritos nefandos, de los frecuentes tratos con los demonios, del concúbito con varones, de la unión incestuosa con hermanas y madres y demás abominaciones de este estilo, se mataban unos a otros sin formación de causa, mezclaban con sangre sus francachelas y borracheras; muchos encontraban sus mayores delicias en comer carne humana; otros inmolaban niños inocentes a los ídolos; otros celebraban las exequias de los suyos con sangre ajena; los más consideraban que la fuerza sólo se les ha dado para hacer daño y ensañarse, al igual que las fieras salvajes que toman por presa suya a los animales naturalmente más débiles y de categoría inferior. De modo que entre ellos ser señor y saquear es una misma cosa; estar sometido no es más que estar expuesto al capricho del más fuerte». Ante tales atrocidades y abominaciones «no parece que se haya de dudar - concluye Solórzano- que nuestros Católicos Reyes hayan podido mover guerra contra los indios para forzarlos a apartarles de estos delitos y a guardar la ley natural» ${ }^{17}$.

En definitiva, los pecados contra la naturaleza, así tomados en su conjunto y sin ulterior especificación, justifican las guerras de conquista. Pero esta conclusión, a la que parece llegar Solórzano, resulta un tanto confusa, porque no se tiene en cuenta una circunstancia que los maestros de la Escuela salmantina consideran esencial; a saber, que los pecados contra la naturaleza, cualesquiera que ellos sean, lleven (o no lleven) aneja una injuria que se infiera al individuo o a la sociedad. Sólo si se da o no se da la circunstancia de la injuria, se puede aclarar el problema en una dirección o en otra.

Al examinar el problema de si la idolatría pueda constituir o no causa justa de guerra, Solórzano se declara perplejo ante la fuerza de los argumentos que se presentan en un sentido y en otro y no se decide a tomar posición clara por una $\mathrm{u}$ otra parte. Pero parece advertirse una cierta inclinación hacia las posiciones de Sepúlveda en el modo de presentar el argumento que pone su fuerza en la conexión existente entre idolatría y blasfemia: «La idolatría y la infidelidad son pecados mayores y más graves que la blasfemia, y la incluyen en cuanto que sustraen a Dios un dominio que le es propio y atacan la fe con su misma ejecución... Ahora bien, por razón de blasfemia se puede hacer la guerra contra los

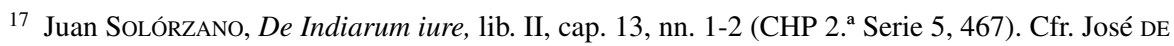
Acosta, De procuranda indorum salute, lib. III, cap. 3. n. 1 (CHP 23, 263). 
infieles, siempre que éstos impidan la fe con sus blasfemias y sus perversas persuasiones u hostiguen a los predicadores de la ley evangélica incluso en sus provincias» $^{18}$.

Dentro de este mismo título sexto para justificar la ocupación de las Indias por España incluye Solórzano la tiranía que padecían los indios antes de la venida de los españoles. Este nuevo aspecto es el que estudia Vitoria en el quinto título de los que él considera legítimos y que formula de la siguiente manera: «Otro título podría ser la tiranía de los mismos caciques de los indios o sus leyes tiránicas en daño de los inocentes; el sacrificio, por ejemplo, de hombres inocentes o la matanza, otras veces, de hombres libres de culpa, con el fin de comer su carne» ${ }^{19}$. Son los diversos matices en que se manifestaba la tiranía de los caciques en daño de los inocentes, es decir, con lesión de unos derechos que les correspondían como a criaturas racionales, imágenes de Dios. Interviene, pues, un elemento nuevo y determinante: la injuria inferida, que rebasa la mera consideración de pecado contra la naturaleza y exige una consideración aparte y autónoma.

Por eso no parece coherente que Solórzano coloque a Vitoria con toda su Escuela en el lado de los que niegan la validez de este sexto título. No lo niegan en lo tocante a este punto fundamental de la tiranía, por las razones aducidas. No se ajusta, por tanto, a la verdad la afirmación de que dichos autores defienden que a los indios «no se les puede hacer la guerra, por más que padezcan la opresión de un tirano, sirvan a los ídolos y comentan los delitos más perversos y abominables contra la ley y la razón naturales; incluso, si, requeridos a que se abstengan de esos desórdenes, rehúsan hacerlo» ${ }^{20}$.

Hubiera sido preciso distinguir entre unos y otros aspectos contra la naturaleza: no se encuentran en el mismo orden la antropofagia, los sacrificios humanos o la blasfemia propiamente dicha, y los desórdenes sexuales o la idolatría, por ejemplo. Consiguientemente, no pueden todos esos aspectos indistintamente constituir una unidad de fundamentación de un mismo título. Es más, incluso la tiranía con todas sus secuelas, que en sí misma considerada es tenida por título válido tanto por Solórzano como por el resto de la Escuela puede tener, a juicio de Alonso de Veracruz, un valor relativo de acuerdo con la idiosincrasia de los pueblos. Por eso, aunque el gobierno de los indios hubiera parecido a los españoles tiránico, todavía le queda a Alonso de Veracruz una duda: «Puede ser que lo que aparece tiránico a los ojos de una nación, fuera conveniente y adecuado a los ojos de esta nación bárbara; por ejemplo, el que sus señores los gobernasen a base de temor y dominio, y no de amor» 21 .

\footnotetext{
18 O. c., lib. II, cap. 13, nn. 39-41 (CHP 2. ${ }^{\text {a }}$ Serie 5, 479).

19 Francisco DE VITORIA, Relectio de indis, I parte, cap. 3, n. 14 (CHP 5, 93).

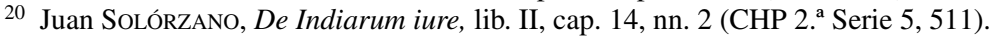

21 Alonso DE VeracruZ, De dominio infidelium et iusto bello, dub. XI (ed. E. J. Burrus, I p. 414, n. $820)$.
}

Hispania Sacra, Missionalia hispanica, 58

117, enero-junio 2006, 263-327, ISSN: 0018-215-X 
De todos modos cuando la tiranía se manifiesta en sacrificios humanos de víctimas inocentes y en antropofagia, nadie duda, como acabamos de indicar, que constituye una causa justa de guerra por la razón tantas veces aludida y que clarifica por sí misma toda esta problemática. Solórzano, en cambio, coloca el pecado de idolatría como punto de partida de su argumentación y por eso necesita, en último término, apuntalar la justificación del título con la consideración de la tiranía: «Pero si en los infieles se halla no sólo la tiranía, sino también una cruel y desenfrenada tiranía, una voracidad de carne humana y cruentos y execrables sacrificios de inocentes..., entonces creo más verdadero y probable la opinión de quienes permiten la guerra contra todos los infieles para acabar con estas injurias y opresiones, aunque no nos estén sometidos y, lejos como están, no demanden nuestra ayuda y se diga que están contentos con su suerte» ${ }^{22}$. Pero es claro que entonces la razón de la idolatría como tal ha perdido toda su eficacia justificativa.

Cuando, finalmente, Solórzano pasa a considerar los pecados de incesto y demás aberraciones sexuales, cree «opinión bastante probable» la de quienes «enseñan que los príncipes cristianos pueden, con licencia del Sumo Pontífice, castigar y hacer la guerra a los indios por causa de estos delitos si, después de advertidos, no desisten de ellos» ${ }^{23}$. Y esta conclusión no es aceptada, como vimos, por Vitoria y su Escuela; no es competencia del hombres castigar y vengar las injurias que se hacen a Dios.

\section{Título séptimo: la predicación de la fe}

Este título séptimo corresponde al cuarto de los que Vitoria considera no legítimos para ocupar las tierras de los indios: «Que no quieren recibir la fe de Cristo, no obstante habérsela predicado y haberles exhortado insistentemente a recibirla» ${ }^{24}$. En torno a él surge una pregunta problemática: ¿Es lícito someter primero por las armas la barbarie de los indios, para que, una vez amansados, reciban después la predicación del Evangelio? Hay dos respuestas antagónicas a estas preguntas: una positiva y otra negativa. La respuesta positiva está representada principalmente por Sepúlveda apoyado en la autoridad de John Mayr. Añade Solórzano que también se puede señalar a Acosta como defensor de esta opinión; pero parece difícil sostener esta afirmación. En efecto, Acosta distingue tres métodos en la predicación de la fe entre los indios: el puramente apostólico sin ningún aparato militar; el de predicar sólo a los convertidos y sometidos; finalmente, el de predicar también a los no convertidos, pero con escolta militar

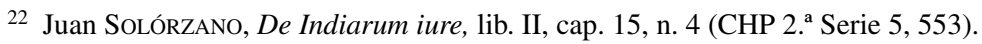

23 O. c., lib. II, cap. 15, n. 26 (CHP 2. ${ }^{\text {a Serie } 5,561) .}$

${ }^{24}$ Francisco DE Vitoria, Relectio de indis, I parte, cap. 3, n. 10 (CHP 5, 54). 
para proteger la vida de los predicadores. Acosta no duda de que el primero es teóricamente el mejor, pero quien quiera seguirlo en todos sus pormenores con la mayor parte de los pueblos indios «por nada más puede ser condenado que por su extrema estupidez, y no sin razón», como lo prueba la experiencia.

Sin abandonar el cuidado pastoral de los ya cristianos, opina Acosta que se ha de llevar el evangelio a los bárbaros no sometidos adoptando el tercer método, porque la razón y la experiencia demuestran «que es preciso que soldado y misionero vayan juntos» 25 .

Pero este tercer método que Acosta defiende para los casos mencionados es muy distinto del que propugna como legítimo en este séptimo título: no se trata de someter previamente por las armas para después predicar, sino de proteger la vida de los predicadores frente a los indios que, por no estar sometidos, podrán alzarse contra ellos, de no mediar la presencia de los soldados. Por la misma razón no parece acertado citar una vez más a Acosta entre los autores que «afirman expresamente que hubiera sido imposible que los españoles convirtieran a los indios, si antes no se les hubiera hecho la guerra o se les hubiera domado por alguna fuerza o temor de armas» ${ }^{26}$.

En el lado opuesto están quienes responden negativamente a la pregunta, es decir, que no se puede forzar en absoluto por las armas ni privar de sus bienes a los indios, aunque sean súbditos de príncipes cristianos, con el fin de predicarles la fe. Solórzano no duda en afirmar que esta es la opinión más generalizada entre los teólogos. Se incurriría en una coacción directa a recibir la fe, que invalidaría el bautismo; aparte de que una conversión forzada sería perjudicial e ilícita, porque la fe es un acto absolutamente libre. Así mismo dirá que mediante coacción directa «nadie debe ser forzado a la fe, porque la fe es una cuestión de persuasión, no de imposición obligada» ${ }^{27}$.

Esto supuesto, preguntamos: ¿dónde se sitúa Solórzano? Por de pronto, una cosa le parece inconmovible: «Poco firme y segura parece la predicación y conversión que introduce la fe con amenazas y temor. Todo el mundo está de acuerdo en que este es un argumento de la máxima fuerza y eficacia que se toma de la Escritura, de los testimonios y ejemplos de los Santos Padres o de la autoridad, tradición o costumbre antiquísima de la Iglesia». Es también la orientación marcada por numerosas cédulas e instrucciones reales ${ }^{28}$.

Es también, por tanto, claro que no se puede nunca ejercer una coacción directa. El problema surge cuando se trata de la coacción indirecta. Cree Solórza-

25 José DE AcosTA, De procuranda indorum salute, lib. II, cap. 8, n. 1; cap. 12, nn. 1-2 (CHP 23, 303-307; 339-341).

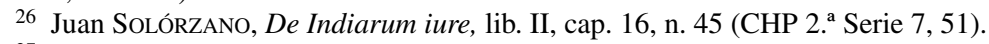

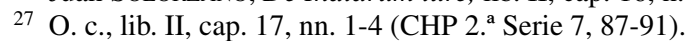

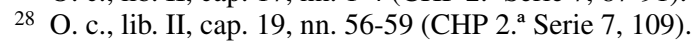

Hispania Sacra, Missionalia hispanica, 58

117, enero-junio 2006, 263-327, ISSN: 0018-215-X 
no que «la opinión constante entre todos los teólogos es que la coacción indirecta no es mala de suyo e intrínsecamente, si se hace en las debidas circunstancias y si con prudencia y con esperanza de perseverancia se pretende como fin la conversión» ${ }^{29}$. Coacción indirecta sería aliviar algo a los indios súbditos «en las cargas y tributos, si quieren convertirse, o imponerles mayores tributos y servicios, si siguen contumaces en su perfidia»; podría extenderse también «incluso a la privación de honores y otros favores y privilegios» ${ }^{30}$. A los maestros de la Escuela opinan unánimemente que a los indios, sean o no súbditos, no se les puede coaccionar ni directa ni indirectamente a abandonar su infidelidad y abrazar la fe, porque incluso la coacción indirecta es un atentado contra la libertad del acto de fe.

No obstante, Alonso de Veracruz no tiene reparo en admitir como lícita la coacción indirecta (con tal de que se evite el escándalo), cuando a los indios no cristianos se les ha propuesto de modo adecuado y suficiente. En ese caso incluso «se les puede obligar con la guerra a recibir el bautismo y la fe, no para que crean con fingimiento, sino para que quieran de corazón lo que antes no aceptaban; es lo que se llama coacción indirecta» ${ }^{31}$. Postura ésta que contrasta por su rigor con la mantenida por la generalidad de los restantes maestros de la Escuela.

Y a esta conclusión precisamente llega también Solórzano en su empeño por defender la validez de este séptimo título: ni admitir como Sepúlveda la coacción directa (eso sería someter primero por la guerra para luego evangelizar), ni rechazar incluso la coacción indirecta, como lo hacen la mayor parte de los maestros de la Escuela de Salamanca. Lo que ocurre es que la ocupación de las Indias sobrepasa con mucho la simple coacción indirecta; y entonces el título séptimo queda radicalmente desvirtuado.

\section{Título octavo: derecho a la predicación, a la emigración y al comercio}

El título octavo, al igual que ocurrió con el sexto, presenta una complejidad que difícilmente puede reducirse a una unidad de concepto. Incluye, en efecto, dos aspectos bien diferenciados, que también considera Vitoria, pero reclamando para cada uno de ellos un concepto autónomo. Estos dos aspectos son: el derecho a la predicación y el derecho a la emigración y comercio.

Hay una cuestión previa: ¿Admite el derecho de predicación lícitamente algún tipo de coacción? Para Solórzano es «opinión muy común y verdadera de

\footnotetext{
29 O. c., lib. II, cap. 18 , n. 22 (CHP 2. ${ }^{\text {a Serie } 7,141) .}$

30 O. c., lib. II, cap. 18, nn. 22, 48 (CHP $2 .^{\text {a }}$ Serie 7, 141, 151).

31 Alonso De Veracruz, De dominio infidelium et iusto bello, dub. XI (ed. E. J. Burrus, I p. 388, n. 760).
} 
casi todos los teólogos y jurisconsultos» la que enseña que es lícita la coacción a escuchar la predicación y a que «deliberen en serio si la deben aceptar o rechazar». Por tanto, se les puede hacer la guerra, «si se resisten tercamente a oír la fe», si bien se han de probar antes todos los medios conducentes a lograr una predicación según métodos apostólicos y pacíficos ${ }^{32}$.

Dando un paso más dice Solórzano que «para confirmar y hacer más amplio este mismo título se puede considerar que nada tiene de extraño afirmar que sea lícito mover guerra contra los infieles que impiden la predicación y propagación del Evangelio, puesto que muchísimos y muy prestigiosos autores, a una con Vitoria, conceden que sí lo es por el solo hecho de que nos prohíban comerciar y negociar sin daño en sus provincias y de que nos cierren el arribo a sus costas y la entrada en sus territorios» ${ }^{33}$. Podría responder Vitoria que tal afirmación sí tiene algo de extraño, puesto que no existe esa pretendida conexión entre impedir la predicación e impedir la comunicación y el comercio. Este segundo aspecto es independiente del primero y no se deriva de él ni tiene cabida en el mismo título, sin que se rompa la unidad del concepto.

Tan es así, que Vitoria lo estudió absolutamente aparte en el primero de los títulos válidos que él llama «de sociedad y comunicación natural» y que desarrolla en estas dos afirmaciones fundamentales: a) «Los españoles tienen derecho a emigrar a aquellos territorios y permanecer allí, a condición de que no se cause daño a los indios; y éstos no pueden prohibírselo». b) «Es lícito a los españoles comerciar con los indios... Y los caciques no pueden prohibir que comercien con los españoles ni, al contrario, a los españoles con los indios» ${ }^{34}$.

La lesión de este doble derecho de hospitalidad y comercio que se debe a toda persona por derecho natural y común de gentes podría justificar, según Solórzano y de acuerdo con los demás autores de la Escuela, una guerra contra los infractores. Tanto más cuanto que, a juicio de Solórzano, el comercio y la hospitalidad son «sumamente necesarios tanto para otros fines como, sobre todo, para la introducción y propagación de la fe» ${ }^{35}$.

\section{Título noveno: el poder del Emperador}

El noveno título es el derecho que pueda tener el Emperador Romano a hacer la guerra a los indios. Vitoria lo recoge en el primero de los títulos no válidos y lo resume en estas dos tesis: a) El Emperador no es señor de todo el orbe.

\footnotetext{
32 Juan SOlÓRZANO, De Indiarum iure, lib. II, cap. 20, n. 1.

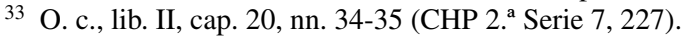

34 Francisco DE Vitoria, Relectio de indis, I parte, cap. 3, nn. 1-2 (CHP 5, 77 y 80).

35 Juan SolóRZAno, De Indiarum iure, lib. II, cap. 29, n. 46 (CHP 2. ${ }^{\text {a Serie } 7,231) .}$
} 
b) Aun suponiendo que lo fuera, no por eso podría ocupar los territorios de los bárbaros ni establecer nuevos príncipes, quitando a los antiguos, y cobrar impuestos $^{36}$.

Solórzano plantea la cuestión en los términos siguientes: «Toda la fuerza de este título consiste en el examen de esta cuestión: ¿Posee el Emperador Romano un poder tal y tan grande sobre las provincias y personas de los infieles que nunca estuvieron sometidas al Imperio Romano, que pueda hacerles lícitamente la guerra y forzarles a reconocer dicho Imperio...?» ${ }^{37}$.

Aunque la respuesta afirmativa se apoya en razones consistentes y tiene muchos y prestigiosos defensores, sin embargo cree Solórzano que «todavía nos resulta mucho más verdadera y segura la opinión de los otros que niegan que pueda tener el Emperador Romano algún derecho en los territorios y provincias de los infieles, sobre todo entre estos bárbaros descubiertos por los españoles sobre quienes jamás los emperadores romanos ejercieron su dominio ni tuvieron noticia de ellos» El poder del Emperador no va más allá de sus propios territorios. Nunca el Emperador fue dueño del mundo entero ni en ninguna parte puede lícitamente disponer de las personas, bienes y territorios de dichos infieles; es más, ni siquiera sobre sus súbditos puede ejercer tal dominio. De aquí deduce Solórzano el escaso o nulo valor que se puede conceder a este título en orden a justificar ante Europa la ocupación de las Indias ${ }^{38}$.

\section{Título décimo: la donación pontificia}

En cambio, el título décimo le merece toda confianza y lo llama «eficacísimo». Es el de la donación pontifica. Un tratamiento a fondo del tema implica el estudio y examen de la doctrina sobre los poderes del Papa. Solórzano dice expresamente que la decisión de la presente cuestión depende de esta otra: ¿El Papa, como Vicario de Cristo en la tierra, tiene poder sobre todos los demás y puede disponer de los reinos y provincias de los cristianos, no sólo en asuntos espirituales, sino también en los temporales?

En Vitoria este título es el segundo de los considerados por él ilegítimos. Su doctrina sobre el mismo puede quedar sintetizada en las siguientes afirmaciones: El Papa no tiene poder temporal sobre todo el orbe; y aunque lo tuviera, no podría concederla a los príncipes cristianos. Sólo tiene poder temporal indirecto en orden a las cosas espirituales; pero no tiene ninguno sobre esos indios y sobre los demás infieles ${ }^{39}$.

\footnotetext{
36 Francisco DE Vitoria, Rele tio de indis, lib. II, cap. 2, nn. 1, 3 (CHP 5, 33, 42).

37 Juan SolóRZANO, De Indiarum iure, lib. II, cap. 21, n. 14 (CHP 2. ${ }^{a}$ Serie 7, 257).

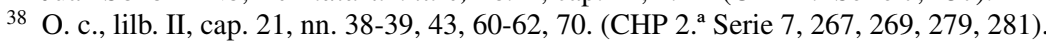

39 Francisco DE Vitoria, Relectio de indis, I parte, cap. 2, nn. 4-9 (CHP 5, 43-53).
} 
Solórzano sostiene, en cambio, que la opinión generalizada es la que concede al Papa, por la entrega de las llaves, jurisdicción suprema y universal en lo espiritual y en lo temporal. No deja de reconocer, sin embargo, que hay «otros» (y cita nada menos que a setenta y tras entre autores antiguos, y los modernos de la Escuela de Salamanca) que adoptan — dice — una vía media entre negar o conceder al Papa suprema jurisdicción: el Papa posee, sin duda, las dos espadas, es decir, suprema potestad espiritual y temporal sobre todos los príncipes seculares; pero la temporal la posee sólo en «hábito», no en «acto». La jurisdicción está como envainada; sólo si por una causa grave así lo exigiera el fin sobrenatural de la fe, podría el Papa hacer uso de ella ${ }^{40}$. Es lo que Vitoria con toda su Escuela llamó potestad indirecta.

¿Cuál es la opinión de Solórzano? Después de exponer los argumentos de los maestros de la Escuela de Salamanca que niegan no sólo al Romano Pontífice, sino incluso a Cristo en cuanto hombre, el dominio temporal sobre todo el mundo, escribe: «A pesar de todo, yo todavía estimo mucho más verdadera y generalizada la opinión contraria afirmativa que establece en el Romano Pontífice la autoridad y poder no sólo indirecto, sino también directo, de la doble espada: la espiritual y la temporal; y le concede, por tanto, supremo dominio y jurisdicción en todos los reinos y provincias de cristianos y no cristianos, cuando así lo exige una causa justa» ${ }^{41}$.

Junto a los argumentos de autoridad añade los de razón: «El Romano Pontífice hace las veces de Dios en la tierra y se dice de él que es el Vicario de Cristo, el Señor, y que constituye un único tribunal con él». Solórzano extrae a partir de aquí las siguientes conclusiones: «El Papa obtiene el supremo principado y monarquía entre todos los príncipes del mundo y es mayor que todos y ha sido constituido príncipe único de todos sobre reyes y reinos, causa de causas, señor de los que dominan y de todas las autoridades, lo es todo y está por encima de todo; a él nadie le puede decir: ¿por qué obras así?, ni juzgar de sus hechos» ${ }^{42}$.

Hay un segundo argumento de razón: Cristo (según la opinión que parece «más y generalizada», dice Solórzano) gobierna, incluso como hombre, la creación entera, porque todo ha quedado sometido a su poder. Y se ha de pensar piadosamente que quiso transmitir este dominio temporal a la Iglesia y al Pontífice que lo representa. Es más, la Iglesia no estaría bien gobernada, «si no estuvieran sometidos al Papa todos los príncipes» ${ }^{43}$.

Puestos estos principios doctrinales, deduce ya Solórzano, a manera de corolario, cuál es el alcance real que se ha de dar a la concesión de Alejandro VI

\footnotetext{
40 Juan SolóRZAno, De Indiarum iure, lib. II, cap. 22, n. 2 (CHP 2. a Serie 7, 291).

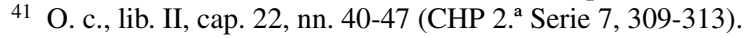

42 O. c., lib. II, cap. 23, nn. 71, 74 (CHP 2. ${ }^{\text {a }}$ Serie 7, 379).

${ }^{43}$ O. c., lib. II, cap. 23, nn. 89-91, 111 (CHP 2. ${ }^{a}$ Serie 7, 367, 375).
} 
como título justificativo de la ocupación de las Indias por España; o, lo que es lo mismo, cuál es el uso concreto que, con motivo de la célebre Bula Inter coetera, ha hecho Alejandro VI de su supremo poder espiritual y temporal.

Solórzano sostiene que muy bien pudo el Papa, en uso de su poder, «confiar a los Reyes Católicos de España no sólo el encargo de convertir las Indias a la fe..., sino también al mismo tiempo concederles el pleno y supremo dominio y jurisdicción y, cuando fuere preciso, hacerles la guerra y conquistarlos». Afirma así mismo que del tenor de la Bula «se deduce suficientemente que el Romano Pontífice quiso conceder a los Reyes Católicos el pleno e íntegro dominio y jurisdicción sobre estos territorio del Nuevo Mundo y sobre los infieles que en ellos habitan, bajo la obligación y condición de que pusieran toda su diligencia en predicar, propagar y conservar entre ellos la fe y la religión cristiana» ${ }^{44}$.

Es claro que Solórzano se mueve a gusto y con familiaridad dentro de la línea (tan cara a Sepúlveda) marcada por el Requerimiento, que redactó Palacios Rubios apoyándose jurídicamente sobre todo en la Bula de Alejandro VI. En este punto importante desatendió Solórzano los razonamientos y la exégesis profunda que de la Bula habían llevado a cabo todos los maestros de la Escuela de Salamanca a partir de Vitoria.

Juan de la Peña, que fue quien quizás estudió más detenidamente este punto, llegó a la conclusión de que lo único que pudo conceder el Papa Alejandro VI a los reyes de España fue lo siguiente:

1. Enviar predicadores;

2. defenderlos contra los que impiden el derecho de predicar;

3. que sólo el rey de España pueda enviar a las Indias predicadores;

4. que los indios puedan libremente aceptarle por rey;

5. que en caso de victoria por guerra justa en la predicación del evangelio, ninguno otro sea rey del territorio sometido;

6. que a los ya convertidos los proteja frente a otros príncipes cristianos y de la esclavitud y tiranía de los príncipes no cristianos;

7. pudo quizás conceder a los reyes de España supremo poder sobre todos los príncipes cristianos y paganos de aquel Nuevo Mundo. Esto es y no más lo único que pudo conceder el Papa a los reyes de España Con la exposición de este «eficacísimo título» cierra Solórzano la argumentación con que defiende a la Corona española ante la Europa protestante por la ocupación y conquista de las Indias.

44 O. c., lib. II, cap. 24, nn. 11, 19 (CHP 2. ${ }^{a}$ Serie 7, 411, 419). 
Desde esta base justificativa queda ya en franquía para seguir avanzando hacia la meta propuesta. La cuestión que ahora se plantea Solórzano, como una prolongación de la que acaba de examinar en el libro segundo, es ésta: ¿Con qué derecho los reyes de España retienen aún hoy día las Indias?. ¿Está justificada la presencia de España en América?

\section{JUSTICIA DE LA PERMANENCIA DE ESPAÑA EN INDIAS}

Justificar la ocupación y conquista es ya en cierto modo, dice Solórzano, probar por anticipado la legitimidad de la retención o permanencia, pues «es más fácil retener algo que conseguirlo de nuevo, y «más fácilmente se tolera el derecho adquirido que el que está en vías de adquirirse», porque «la continuación es natural, no así una nueva adquisición» ${ }^{45}$.

Esto quiere decir que determinados títulos que justifican la ocupación bien pudieran convertirse también en base justificativa de la retención, por vía de prolongación. Es lo que ocurre con el título de la concesión pontificia. «El mismo Pontífice en persona, Alejandro VII, que encomendó a los Reyes Católicos su explotación [del Nuevo Mundo], les concedió también su retención y posesión a ellos y a sus sucesores perpetuamente», y no exclusivamente el cuidado de la conversión o la mera administración y vigilancia de los indios. El Pontífice quiso dar un paso más y les concedió «con palabras encarecidas y reiteradas... pleno señorío y omnímoda libertad de acción, potestad y jurisdicción en asuntos temporales». Y en este sentido entendieron ellos siempre la donación. Pero bien entendido que la concesión pontificia no convierte a los reyes de España en feudatarios de la Santa Sede, sino que gozan de plena autonomía y jurisdicción ${ }^{46}$.

\section{Título primero de la retención: la concesión pontificia}

Este, pues, sería el primer título justificativo de la retención o permanencia de España en Indias. Es claro que las mismas limitaciones que los maestros de la Escuela imponían a la validez del título en orden a la ocupación y conquista siguen conservando su fuerza, cuando se trata de prolongarlo hasta justificar también con él la retención y permanencia.

Si la concesión pontificia no da a los españoles ningún derecho para ocupar los territorios de los indios, tampoco les da derecho para retenerlos; puesto que

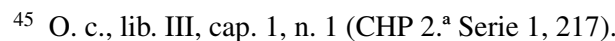

46 O. c., lib. III, cap. 1 , nn. 13-15, 21, 41-45 (CHP 2. ${ }^{a}$ Serie 1, 219, 221, 227-229).

Hispania Sacra, Missionalia hispanica, 58

117, enero-junio 2006, 263-327, ISSN: 0018-215-X 
estarían reteniendo algo que no les pertenece. La razón de Vitoria sigue en pie: el Papa no puede conceder lo que no es suyo. Y no es suyo el Nuevo Mundo, porque no tiene ningún poder temporal sobre esos indios. Si la permanencia de España en Indias tras su ocupación está justificada, será por otras razones, pero no por la propia concesión pontificia.

\section{Segundo título de la retención: la madura deliberación de los reyes}

El segundo título justificativo de la retención del Nuevo Mundo lo formula Solórzano en estos términos: «Que los Reyes Católicos emprendieron su conquista después de prolongado y maduro examen y siguiendo una opinión probable. Y lo que una vez quedó ya bien discutido y legítimamente mandado, no debe someterse de nuevo a deliberación». La consecuencia es que desde el punto de vista moral se pusieron todos los medios para que la ocupación de las Indias se hiciera con buena y segura conciencia. En definitiva, los reyes procedieron y siguen procediendo con buena conciencia reteniendo las Indias y permaneciendo en ellas.

Como quiera que sea, tendría aplicación al caso de nuestros reyes la docrina generalmente admitida en Moral y aducida por Solórzano, según la cual quien caiga en error por seguir el parecer de los expertos, queda excusado de toda culpa, tanto en el fuero interno como en el externo. Precisamente Vitoria, en su preámbulo a la disertación sobre la licitud de la conquista y permanencia de España en Indias, expone los principios morales sobre los que Solórzano apoya la validez del presente título, en estas tres fundamentales:

a) «En materia dudosa debe consultarse con aquellos a quienes compete instruir sobre el caso...

b) Si consultados los expertos, éstos define que es ilícita aquella materia dudosa, cada cual está obligado a seguir la opinión de los mismos, y si hace lo contrario, no tiene excusa, aunque por lo demás la cosa de suyo fuera lícita.

c) Por el contrario, si hecha la consulta sobre materia dudosa, los expertos han definido que aquello es lícito, está seguro quien siga su opinión, aunque por lo demás fuese ilícito» ${ }^{47}$.

Para confirmar la tesis, no deja de recordar Solórzano la doctrina de aquellos doctores para quienes se obra con conciencia segura e incluso abrazando opiniones sólo probables, aunque haya otras más seguras y probables. Y Solórzano

\footnotetext{
47 Francisco DE Vitoria, Relectio de indis, I parte, nn. 5-7 (CHP 5, 9-10).
} 
saca la conclusión: «Nuestros reyes pueden con justicia y seguridad retener los territorios que conquistaron y adquirieron, habiendo precedido esas consultas ${ }^{48}$. Tanto más cuanto que esta buena fe, así demostrada ininterrumpidamente desde los comienzos mismos del descubrimiento y ocupación, fundamentará y hará posible una razón de orden jurídico: la prescripción de buena fe, aceptada por el derecho de gentes.

\section{Título tercero de la retención: la prescripción de buena fe}

Es el título que, a juicio de Solórzano, justifica la retención de las Indias. Por eso manifiesta su expresa intención de examinarlo a fondo y «defenderlo de algunas diversas calumnias de los protestantes», convencido de la necesidad de la prescripción, sobre todo para resolver los contenciosos entre los soberanos y en definitiva para hacer posible la convivencia humana. Eliminar la prescripción sería «arrojar en el mundo la semilla de las guerras en que arderá el orbe entero» ${ }^{49}$.

Es una idea muy presente también en José de Acosta, a quien Solórzano expresamente cita en este punto en apoyo de su tesis. Acosta, en efecto, había dejado diáfanamente formulada la tesis de la prescripción aplicada a la retención de las Indias por parte de España, con la siguientes palabras: «Y no es que yo me ponga ahora a defender las guerras y títulos de guerras pasadas... ni a justificar las destrucciones, represalias, matanzas y demás disturbios de años anteriores en el Perú. Pero sí advierto, por razones de conciencia y de interés, que no conviene seguir disputando más en este asunto, sino que, como cosa que ya ha prescrito, el siervo de Cristo debe proceder con la mejor buena fe ${ }^{50}$. En páginas posteriores afirma Acosta que si no admitimos la prescripción (de acuerdo con las condiciones señalas por el derecho) en orden a legitimar determinados imperios, «las relaciones humanas desembocarán en un caos universal» 51 .

La prescripción (en el caso de las Indias Occidentales) alcanza no sólo a los territorios ocupados y a su retención, sino también al dominio sobre los litorales e incluso sobre la navegación y comercio, que se podrían prohibir por derecho a los extranjeros. Esta ampliación viene provocada por la respuesta que Solórzano da a Hugo Grocio (el Autor Desconocido, como él dice), que negaba dicho derecho por considerar que los mares son de derecho común inviolable e imprescriptible.

\footnotetext{
48 Juan de Solórzano Pereira, De Indiarum iure, lib. III, cap. 3, n. 40 (CHO 2. ${ }^{\text {a }}$ Serie 1, 269).

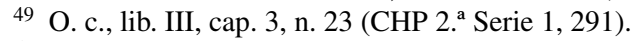

50 José DE ACOSTA, De procuranda indorum salute, lib. II, cap. 11, n. 1 (CHP 23, 333).

51 O. c., lib. III, cap. 3, n. 2 (CHP 23, 401).
}

Hispania Sacra, Missionalia hispanica, 58

117, enero-junio 2006, 263-327, ISSN: 0018-215-X 
La respuesta está últimamente montada sobre el título, anteriormente examinado, del poder universal del Papa en el que apoya Solórzano su interpretación del amplísimo alcance de la Bula Alejandrina. Consiguientemente, la validez de la respuesta viene condicionada por la validez misma del título. Concede Solórzano a Grocio que el mar y los derechos de navegación y comercio son comunes, pero no así los mares y las costas de esos mismos dominios. Sobre ellos pueden ejercer los supremos soberanos una tutela y jurisdicción e incluso establecer impuestos portuarios. Con mayor razón la pueden ejercer nuestros reyes por apoyarse en el firme derecho de la donación pontificia y por haber sido los primeros en hacer tantas veces la travesía con sus flotas, en predicar y comerciar en los territorios indios con cuantiosos gastos y durante tantos años, en exclusiva e inclusión con exclusión de los demás ${ }^{52}$.

Vitoria ya había apuntado a estas razones, si bien no trataba expresamente el problema de la jurisdicción sobre los mares ni de la prescripción. Aunque sólo admitía el poder indirecto del Papa en asuntos temporales y concedía, como vimos, un alcance muy limitado a la donación pontificia, sin embargo, basado en ese mismo poder indirecto, sostenía que el Papa podía encomendar a los reyes de España la predicación del evangelio y prohibirla a los demás; y no sólo prohibirles la predicación, sino también el comercio, si así convenía la propagación de la religión cristiana. Es más, «como quiera que los soberanos españoles fueron los primeros que bajo sus auspicios y con su dinero emprendieron aquella travesía y descubrieron tan felizmente el Nuevo Mundo, justo es que tal empresa sea prohibida a los demás y ellos disfruten de lo descubierto» ${ }^{53}$.

Mas a esto hay que añadir los derechos que otorga la doctrina de la prescripción, admitida por el derecho común de gentes, cuando ésta se apoya en un largo período de treinta o cuarenta años. Y Solórzano hace resaltar que, en el caso de nuestros reyes, «resulta que hace ya más de ciento treinta años que se encuentran en una especie de posesión y costumbre continuada e ininterrumpida, de suerte que sólo ellos navegan por estos mares a los territorios de ambas Indias y se lo prohibían a los extranjeros que querían acercarse a sus puertos» 54 .

Es absolutamente falsa la acusación a nuestros reyes de falta de buena fe, por las razones ya expuestas; aparte de que muchos opinan que tras una prescripción inmemorial ya no tiene sentido discutir sobre la buena fe. «Y añado que, aunque [nuestros reyes] tuvieran conciencia dudosa, todavía habría que considerarles poseedores de buena fe», de acuerdo con la doctrina moral sobre conciencia dudosa, comúnmente admitida ${ }^{55}$.

52 Juan De SolóRZAno Pereira, De Indiarum iure, lib. III, cap. 3, nn. 35-50, 56-59 (CHP 2. a Serie, 1, 297-303).

53 Francisco DE Vitoria, Relectio de indis, I parte, cap. 3, n. 9 (CHP 5, 88-89).

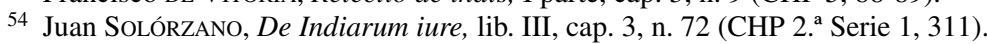

55 O. c., lib. III, cap. 3, n. 80 (CHP 2. ${ }^{\text {a }}$ Serie 1, 315). 
En definitiva, Solórzano hace extensiva la validez del título de prescripción no sólo a la retención de los territorios ocupados de las Indias, sino también de las costas y mares adyacentes en la medida en que posibilitan el comercio y todas aquellas ayudas de carácter espiritual o material necesarias para la evangelización y gobernación de dichos territorios. Era preciso aclarar este último punto, convertido en polémico en el resto de Europa por medio, sobre todo, de Hugo Grocio (el Autor Desconocido, como él dice), que con su obra Mare liberum ponía en peligro la seguridad de la navegación, el comercio y el gobierno de España en Indias.

Acumula luego Solórzano títulos de diverso tipo, que engloban problemas tanto de conquista como de retención. «Nuestros cristianísimos reyes —afirma- retienen sin sombra de duda unas provincias en las que los indios no han querido recibir ni escuchar la fe que se les ha anunciado pacíficamente y con suficiencia, o una vez recibida la han abandonado, han blasfemado de ella o han puesto impedimentos; o han hostilizado a los españoles que se acercaban a ellos para predicarles y comerciar con ellos, que pedían pasar a otras regiones sin causar perjuicio; o después de haberles acogido con fingida hospitalidad, les dieron muerte en incursiones pérfidas y astutas». Y concluye a renglón seguido: «Como en estos casos justa y legítimamente se puede declarar la guerra a los no cristianos (de acuerdo con las razones que discutimos a fondo antes), con mucha más justicia se retendrá lo adquirido en tal guerra o se podrá ir a la guerra de nuevo, si fuera necesario, para conservarlo y retenerlo» ${ }^{56}$. Solórzano presenta aquí tanto el título de conquista como el de retención dándose mutuamente apoyo.

\section{Título cuarto de la retención: la ayuda a los aliados}

Lo mismo cabe observar sobre lo que Solórzano considera «un título justísimo de conquista y muchísimo más de retención de las Indias»; y se refiere a la ayuda prestada por los españoles a los que se la reclamaban por pactos de alianza y amistad para defenderse de sus enemigos en guerra justa. «Así hizo en Nueva España en el caso de los tlaxcaltecas contra los mexicanos». Y recuerda expresamente el propio Solórzano que es el título que Vitoria llama séptimo y último «por el que pudieron o podrían venir los indios y sus territorios a posesión y poder de los españoles» ${ }^{57}$.

Pero aquí el caso de los tlaxcaltecas ofrece algunos motivos de reflexión. A lo sumo podría explicar la ocupación y consiguiente retención de aquellos te-

\footnotetext{
56 O. c., lib. III, cap. 4, nn. 1-2 (CHP 2. ${ }^{\text {a Serie } 1,323) .}$

57 O. c., lib. III, cap. 4, nn. 18-19 (CHP 2. ${ }^{\text {a Serie } 1,331) .}$
} 
rritorios que por el derecho de guerra justa y en virtud de los pactos de alianza a amistad establecidos podría en justicia corresponde a los españoles. Pero una vez más es Veracruz, profundo conocedor de la realidad mexicana, quien vuelve a levantar la duda. No cree que por este título quede justificado el dominio de los españoles. «Primero, porque no hay certeza de la justicia de la guerra por parte de los tlaxcaltecas; en segundo lugar, porque, aunque hubiera habido justicia, pero no hasta privarles de sus dominios, y en tercer lugar, tampoco hasta despojarles de su tesoro». Por consiguiente, «si los españoles se hicieron dueños de los tlaxcaltecas sólo por este título..., han usurpado sus dominios y están obligados a la restitución de todo» 58 .

\section{Título quinto de retención: el libre consentimiento}

Otro título, incluso más apremiante, a favor de la legítima retención del Nuevo Mundo es el libre consentimiento de los indios: «Al conocer la religiosidad, el poderío, la prudencia en el gobierno y la mansedumbre de nuestros reyes, se entregaron a su imperio, gobierno y jurisdicción con total voluntad y entusiasmo». Incluso hace mención Solórzano (para confirmar la legitimidad de este título) de unos acuerdos logrados en 1562, por los que consta que el Virrey Conde de Nieva envió a Polo de Ondegardo a casi todas las provincias del Perú para explorar la voluntad de los indios en el asunto de la perpetuidad de las encomiendas. Y respondieron «unánimemente que ellos no querían tener ni elegir o reconocer en el futuro a otro señor general o particular fuera de nuestro rey de España..., a quien sometían sus personas y bienes humildemente y contentos». Solórzano formula la conclusión definitiva: «Supuesto este consentimiento, aunque se hubiese podido quizás reprobar algún exceso o fallo de justicia en los comienzos de la primera conquista, parece que ha quedado ya totalmente borrado y reparado». Incluso un régimen tiránico podría convertirse en monarquía legítima por el consentimiento expreso o tácito de los pueblos a lo largo del tiempo $^{59}$. La legitimidad de la retención queda, por tanto, a salvo de cualquier duda.

Tiene razón Solórzano en apuntalar su tesis con los nombres más brillantes de la Escuela de Salamanca. Es, efectivamente, un título unánimemente reconocido por sus maestros. Más aún, es en última instancia el único título plenamente eficaz que se basta a sí mismo. Vitoria lo formula con toda claridad casi con las mismas palabras en el sexto lugar de los válidos: «Si los indios mismos, comprendiendo el gobierno prudente de los españoles y su humanismo, quisie-

58 Alonso De Veracruz, De dominio infidelium et iusto bello, dub. XI (ed. E. J. Burrus, I p. 426, nn. 852, 855). $337)$.

59 Juan De SolóRzano Pereira, De Indiarum iure, lib. III, cap. 4, nn. 33-36 (CHP 2. ${ }^{\text {a }}$ Serie 1, 
ran libremente, tanto los caciques como sus súbditos, aceptar como soberano al rey de España» ${ }^{60}$.

Esto parece incuestionable. El problema está, como siempre, si se cumplen en la realidad las condiciones de aplicabilidad del título: es decir, si verdaderamente hubo consentimiento libre en el caso de las Indias. Solórzano lo asegura y aduce como prueba los mencionados acuerdos de 1562. A pesar de todo, no parece que los maestros de la Escuela estén de acuerdo en que hubiera quedado a salvo la verdadera libertad del consentimiento. El procedimiento jurídico que normalmente se utilizaba en la primera época de la ocupación para inducir a los indios a la aceptación del dominio español era el «Requerimiento», que por su misma estructura no ofrecía garantía de ninguna clase para salvaguardar la libertad de un acto de tal trascendencia.

Por eso Vitoria niega que hubiera elección voluntaria. Porque para que ésta se dé, no deben «intervenir el miedo y la ignorancia que vician toda elección. Ahora bien, ambos factores intervienen en aquellas elecciones y aceptaciones; pues lo indios no saben lo que hacen ni aun quizás entienden lo que les piden los españoles. Además, se lo piden a una turba inerme y medrosa, a la que rodean con las armas en la mano» ${ }^{61}$.

Veracruz nos transmite la misma impresión envuelta en inquietantes dudas sobre lo que fue la ocupación de México, y no despeja la condición de libertad que se exige para la validez de este título. Porque si el consentimiento - dicefue forzado por el miedo a unos hombres que venían armados, «no bastaría, aunque lo hubiera dado todo el pueblo» ${ }^{62}$.

La conclusión entonces es que, si no han existido plenas garantías de libertad, este título no justifica ni la ocupación ni la consiguiente retención. Esta consideración alcanza, naturalmente, a los acuerdos de 1562, que, por otra parte, quedan limitados exclusivamente a los territorios afectados por los mismos. Su validez real (ni digo ya jurídica) depende de cómo históricamente se hayan desarrollado los hecho.

\section{Título sexto de la retención: la imposibilidad de devolución}

Pasa finalmente Solórzano a estudiar el último título justificativo de la retención que dice ser «el más eficaz». Y es la imposibilidad de una devolución de las Indias, dada la situación que se ha creado en el curso de los acontecimien-

\footnotetext{
60 Francisco DE Vitoria, Relectio de indis, I parte, cap. 3, n. 15 (CHP 5, 94).

61 O. c., I parte, cap. 2, n. 23 (CHP 5, 73).

62 Alonso DE Veracruz, De dominio infidelium et iusto bello, dub. XI (ed. E. J. Burrus, I p. 430, n. $860)$.
}

Hispania Sacra, Missionalia hispanica, 58

117, enero-junio 2006, 263-327, ISSN: 0018-215-X 
tos. En el desarrollo de la idea aparecen entremezclados indistintamente tres aspectos mutuamente conexos que conviene contradistinguir. Existe, en primer lugar, una imposibilidad práctica, por decirlo así, que podríamos caracterizar con esta doble pregunta: ¿a quién y cómo? Existe, en segundo lugar, una imposibilidad de tipo moral, que podríamos sintetizar en estas palabras: el abandono sería un pecado grave. Y existe, en tercer lugar, una imposibilidad de carácter socio-político, en cuanto que las Indias constituyen ya una comunidad sociopolítica de indios y españoles con mutuas e inextricables relaciones humanas, que no se pueden destruir. Y esto aun supuesto de que «en la conquista del Nuevo Mundo y en la conversión de los indios hubiera intervenido en aquellos primeros tiempos algún paso que hiciese menos justa y legítima la ocupación y el dominio de nuestros reyes.

A manera de preámbulo y de contexto histórico señala Solórzano que hoy por hoy ya todo el mundo reconoce al rey de España como señor del Nuevo Mundo después de la ingente tarea allí desarrollada ${ }^{63}$. Es justamente la idea que cincuenta años antes había expresado el Superior General de la Compañía de Jesús, Everardo Mercuriano, en carta al Visitador de los jesuitas en Indias, P. Juan de la Plaza, que se debatía entre dudas de conciencia sobre la legitimidad del dominio español en América. Este era para Plaza el «punto principal». Mercuriano le tranquilizó con estas palabras: «Acerca del punto principal del señorío y dominio universal de las Indias, deseo mucho que Vuestra Paternidad dexe las dubdas que se le ofrescen, pues no hay que dubdar en ello habiéndose determinado y reconociendo el mundo por legítimo señor al Rey» ${ }^{64}$.

Desde este mismo reconocimiento universal como preámbulo es desde donde afronta Solórzano su último y más eficaz título de la imposibilidad de la devolución. Una imposibilidad, en primer lugar, práctica, como se indicó, de acuerdo con la opinión de José de Acosta, cuyas palabras transcribe Solórzano como testimonio de autoridad al que se adhiere plenamente: «... porque aun concediendo que se hubiera pecado gravemente en la usurpación del dominio de las Indias, sin embargo, ni se puede ya restituir — ¿a quién y cómo? - y sobre todo porque, aunque se pudiese, de ninguna manera lo sufriría ni la evidente injuria que se haría a la fe cristiana, una vez aceptada, ni el peligro a que se expondría» 65 .

Estas últimas palabras, que hace Solórzano suyas, expresan claramente la obligación moral que los reyes tienen de permanecer en las Indias, es decir, la imposibilidad moral de abandonarlas o de devolverlas. Es una tesis, defendida por todos los maestros de la Escuela de Salamanca; España no puede abandonar

63 Juan DE SolóRZAno Pereira, De Indiarum iure, lib. III, cap. 5, nn. 1-2 (CHP 2. ${ }^{a}$ Serie 1, 347).

64 Monumenta Historica S.J., Monumenta Peruana, I, p. 659, n. 1.

65 José DE Acosta, De procuranda indorum salute, lib. II, cap. 11, n. 2 (CHP 23, 333). 
las Indias. Vitoria la formula con descarnado laconismo: «Es evidente que después que se han convertido allí muchos indios, no sería conveniente ni lícito al rey abandonar del todo la administración de aquellos territorios» ${ }^{66}$ Veracruz mantiene la misma tesis con respecto a la presencia de España en México: sea lo que sea de la justicia en los comienzos, en las actuales circunstancias la necesidad de mantener la fe recibida y salvar la convivencia pacífica entre españoles y mexicanos justifica, sin lugar a dudas, que esté en manos del Emperador Católico ${ }^{67}$.

Solórzano se siente, pues, bien apoyado por esta opinión generalizada de los maestros de la Escuela y confirma la tesis por la incapacidad que tienen los indios para autogobernarse: «Por tanto, se les ha de gobernar y proteger con el mando supremo de los españoles» ${ }^{68}$. Y añade Solórzano que esta es también la opinión de Vitoria. Y es verdad, pero con unos matices que es preciso tener en cuenta. Vitoria, en efecto, habla de un discutible título para retener las Indias, que no se atreve a dar por bueno, pero tampoco a condenarlo del todo: si realmente los indios no son de modo alguno capaces, por su barbarie e incultura, de gobernar una república ordenada, «podría entonces decirse que para utilidad de ellos, podrían los reyes de España encargarse de su gobierno y nombrarles ministros y gobernadores... para sus pueblos; es más, incluso nuevos gobernantes mientras se viere que les conviene» ${ }^{6}$.

Existe, además, el peligro de que los indios vuelvan a la idolatría, si se les deja en manos de sus caciques. De hecho tal peligro fue confirmado por numerosos informes confidenciales o testimonios fidedignos de visitadores y misioneros del siglo XVI, a muchos de los cuales (precisamente por el carácter confidencial de los mismos) no pudo tener acceso Solórzano. La conclusión era que a los indios, una vez cristianos (del modo que sea, por métodos legítimos o reprobables), no se les puede abandonar; y puede el Papa «en beneficio de la fe, lo pidan ellos o no lo pidan, darles un príncipe cristiano y quitarles los otros príncipes no cristianos» ${ }^{70}$.

${ }^{66}$ Francisco DE Vitoria, Relectio de indis, I parte, cap. 3, n. 17 (CHP 5, 99).

67 Alonso DE Veracruz, De dominio infidelium et iusto bello, ed. E. J. Buurrus, I, p. 460, n. 930).

68 Juan SolóRZAnO, De Indiarum iure, lib. III, cap. 5, nn. 4-6 (CHP 2. a Serie 1, 351).

69 Francisco DE Vitoria, Relectio de indis, I parte, cap. 3, n. 17 (CHP 5, 97).

70 Juan DE SolóRZAno Pereira, De Indiarum iure, lib. III, cap. 5, nn. 4-8, 21-22 (CHP 2. ${ }^{a}$ Serie 1, 351, 335-337). Un testimonio impresionante (a manera de ejemplo) del peligro de vuelta a la idolatría, al que alude aquí Solórzano, lo tenemos en la carta que Fray Solano, obispo de Cuzco, escribe desde Lima al Emperador Carlos V el 10 de marzo de 1545, con motivo de la puesta en ejecución de las Nuevas Leyes: «Y esta libertad que tomaron los indios vi que los indios que estaban doctrinados en nuestra santa fe católica y la sabían y eran cristianos batizados, vilos sin fe y en sus ritos y sacrificios y leyes como solían, vueltos a sus caciques y a sus pueblos como antes... Y el recebimiento que sus caciques les hacían era sacrificallos porque eran cristianos y habían servido a cristianos. Y esto era muy público por los caminos. Y de un cacique yo soy testigo, porque se lo reñí; y él me confesó que había sacrificado una india» (CHP 27, 130).

Hispania Sacra, Missionalia hispanica, 58

117, enero-junio 2006, 263-327, ISSN: 0018-215-X 
En definitiva, hay una imposibilidad moral de devolver o abandonar las Indias; o, empleando una formulación positiva, hay una obligación grave de conciencia de retener las Indias y permanecer en ellas mientras perduren la situación descrita y los inquietantes riesgos a que quedaría sometida la fe, todavía poco firme, de la población indiana, si los reyes de España abandonasen la administración y gobierno de aquellos territorios. La coincidencia en este punto con la doctrina de la Escuela salmantina es plena.

A este respecto no admite duda el parecer del arzobispo de Lima Fr. Jerónimo de Loaysa, que con la firma de los Superiores Provinciales del Perú envió el 8 de enero de 1586 al Presidente de la Real Audiencia de Lima, Licenciado Castro. En él se señala como primer presupuesto «que Su Majestad es obligado a sustentar esta tierra ansí en la doctrina como en la justicia y que pecaría mortalmente, si la desamparase, como se determinó en la Junta que se hizo ansí por letrados teólogos como por juristas, año de cuarenta y dos» ${ }^{71}$.

Incluso el Licenciado Falcón, defensor y abogado de los indios por comisión de ellos, en el informe presentado en 1567 al Segundo Concilio Provincial de Lima, después de elogiar la disposición del Emperador a devolver los reinos de las Indias, añade «que justa y cristianamente le fue respondido que no le era lícito dexarlos a cuyos eran, por los grandes daños que a los mesmos señores y súbditos se les seguirían de ello, tornándose a su infidelidad, y la ofensa que se hiciera a Dios Nuestro Señor y injuria a la religión cristiana...» 72 .

Hay, finalmente, una tercera imposibilidad de tipo político en abandonar las Indias: españoles e indios forman ya hoy en día una comunidad «constituida bajo la protección y gobierno de un mismo y común rey español. Y la situación, fuerzas y nervios de uno y otro reino están tan imbricados y trabados, que no se pueden separar el uno del otro sin grande y evidente peligro y perjuicio de ambos» ${ }^{73}$. Es una idea que ya había expuesto con toda claridad José de Acosta; europeos e indios están constituyendo una misma república indiana, en cuya conservación están comprometidos, por derecho natural, todas las partes. «Toda la población de indios y españoles —escribe- hay que considerarla ya como una sola e idéntica comunidad política, y no dos distintas entre sí: todos tienen un mismo rey y unas mismas leyes; un mismo tribunal los juzga a todos, y no hay un derecho para unos y otro para otros, sino para todos el mismo» ${ }^{74}$.

Así mismo el Visitador y Oidor de la Audiencia Real de Guatemala, Licenciado Tomás López Medel, escribía a los reyes de Bohemia en el amplio y confidencial informe de marzo de 1551: «Es otro presupuesto... que entendamos

\footnotetext{
71 Carta magna de los indios. Fuentes constitucionales, 2534-1609 (CHP 27, 167).

72 O. c. (CHP 27, 176).

73 Juan SolóRZAno, De Indiarum iure, lib. III, cap. 5, nn. 25-27 (CHP 2. ${ }^{a}$ Serie, 357-359).

74 José DE Acosta, De procuranda indorum salute, lib. III, cap. 17, n. 7 (CHP 23, 517).
} 
por allá y por acá que el bien o el mal de estas dos repúblicas, de los españoles y de los naturales, que acá se fundan para servicio de Dios y de Vuestra Alteza, está tan conjunto y han de ser tan fraternizadas y crescer y correr a la par, que el que quisiera aprovechar a la una con daño de la otra, ni aprovecha a la que quiso y destruye a la otra... Son tan necesarios los unos a los otros, que los unos sin los otros no harán bien su negocio, y son por agora como carne y hueso. La carne sin el hueso corrómpese luego, y el hueso sin la carne sécase luego y pierde su virtud» 75 .

Indudablemente destacadas personalidades formadas en el espíritu de la Escuela de Salamanca, que durante largos años habían vivido día a día en contacto directo con la realidad indiana, apoyaban plenamente, desde su profunda y privilegiada experiencia, las razones con que Solórzano demuestra aquí la obligación moral que tiene la Corona española de permanecer en el Nuevo Mundo; la situación político-religiosa de la nueva sociedad indiana hacía imposible el abandono, sin incurrir en una gravísima responsabilidad de conciencia por la situación de desastre y caos que se crearía con tal medida.

En conclusión, los reyes de España no sólo no están obligados a restituir las Indias, sino que por el contrario están obligados a retenerlas y permanecer en ellas, mientras no se obtengan las condiciones políticas, sociales y religiosas que hagan viable la convivencia humana en la nueva sociedad indiana. A veces - dice Solórzano siguiendo a San Agustín - será necesario tolerar determinados abusos para evitar daños mayores.

Sin embargo, queda todavía por aclarar un aspecto que atañe directamente a la responsabilidad de los reyes: ¿Ha habido siempre realmente una cuidadosa selección de las personas que han pasado a las Indias con cargos de administración o de gobierno? Pero justo aquí es cuando surge el problema: Ciertamente ha habido abusos, y muchos de ellos muy graves, que han dado base a las acusaciones lanzadas contra España por los protestantes de Europa. Solórzano se pregunta: ¿En qué grado pueden quedar comprometidos los reyes? ¿Cuál es la responsabilidad ante los abusos cometidos, especialmente en la primera etapa de la ocupación? Caso de haber incurrido en estas responsabilidades, ¿no quedaría viciada de raíz la legitimidad de la retención invalidando de hecho todos los títulos para ella? Aquí está el origen de las principales acusaciones que la Europa protestante lanza contra España y sus reyes. Una vez justificado el derecho de la Corona a ocupar y retener las Indias, es preciso ahora enfrontar directamente esta acusaciones para darles una respuesta adecuada.

75 Tomás LóPEz Medel, Colonización de América. Informes y testimonios (CHP 28, 81-82).

Hispania Sacra, Missionalia hispanica, 58

117, enero-junio 2006, 263-327, ISSN: 0018-215-X 


\section{Respuesta a las acusaciones contra España}

Si no hay comienzo legítimo - dicen los adversarios-, si la base es errónea y está viciada, todo se derrumba; los orígenes condicionan cuanto de ellos se deriva. Pues bien, la conquista y la retención de las Indias tienen unos comienzos viciados. No era el celo apostólico lo que movía a los primeros conquistadores, sino la codicia y la sed de oro. En su respuesta Solórzano reconoce el hecho y no cree que sea para indignarse tanto, pues nada tiene de extraño - dice- que unos soldados, gente plebeya y mundana, se sintieran movidos por el afán de riquezas. Pero este hecho no empaña «la cristiana legislación de nuestros reyes y el sincero cuidado de otros varones religiosos y su insobornable tarea apostólica» ${ }^{76}$.

Los codiciosos — siguen objetando los protestantes - no aman la paz. Y esto es lo que se ha comprobado en las Indias: por la codicia del oro los españoles trataron tiránicamente a los indios y así los arrasaron y lo perturbaron todo con guerras y espantos. Solórzano no podía negar estos lamentables hechos confirmados por numerosos testimonios históricos. Los admite sin reticencias: «Yo no puedo ni debo, naturalmente, excusar totalmente todas las guerras y abusos de guerras emprendidas, ni todos aquellos atropellos de los primeros tiempos, ni las crueldades que dice haberse cometido contra los indios. Pero sí ciertamente advierto con toda energía — dice que, si en estos hechos se pecó, no por ello... sale perjudicada en absoluto la religiosidad de nuestros reyes y sus derechos», porque siempre han procurado lo mejor para los indios. Y Solórzano hace un amplio recorrido por las principales instrucciones, ordenanzas y cédulas reales que fueron apareciendo ya desde los primeros años del descubrimiento, en las que ininterrumpidamente se toma con toda decisión la defensa de los indios frente a cualquier abuso de españoles y se insta una y otra vez en su buen trato, conservación e instrucción ${ }^{77}$.

En esta postura de Solórzano hay dos puntos de coincidencia con el sentir común no sólo de los maestros de la Escuela salmantina en general, sino también de todos aquellos que en Indias desempeñaron cargos de gobierno tanto en la esfera civil como eclesiástica. Todos, efectivamente, coinciden en reconocer y alabar la prudencia, sentido cristiano y altura moral de la legislación emanada de la Corona, y por tanto en exculpar a los reyes de los atropellos, crímenes o acto de crueldad cometidos contra los indios, porque siempre - pensabancastigaron con severidad los excesos y procuraron aplicar el debido remedio a los males que iban surgiendo en la sociedad indiana.

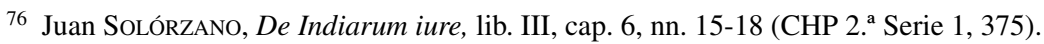

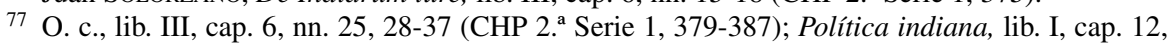
nn. $1-8$. 
Sería inacabable aducir testimonios en este sentido de una y otra tendencia, pertenecientes a uno u otro estamento. El Bachiller Luis Sánchez en un Memorial dirigido en 1566 al Presidente del Consejo de Castilla, Espinosa, sobre la despoblación de las Indias lo formula con absoluta claridad: «Quién tenga la culpa de tantos males, yo lo diré. No la tiene nuestro buen rey y señor, como algunos, atrevida y malamente, sin entendello, hablan. Porque bastantísimamente descarga con poner un Consejo tan cristiano y de tantas letras, y él tan de buena gana oye a todos; y lo que a su noticia viene, manda remediar... Pues el Consejo de Indias tampoco tiene culpa de estos males, pues con diligencia hace lo que en sí es, procurando de enviar allá obispos y jueces los mejores que puede hallar. Y si allá se pervierten, ¿qué culpa tiene? Basta hacelles tomar residencia [juicio en que se pide cuenta de la gestión administrativa] y castigallos, pues la provisiones, cédulas, instrucciones que envía y lo que allá manda, santísimo es» ${ }^{78}$.

El otro punto de coincidencia es la necesidad de distinguir tiempos a la hora de repartir responsabilidades. Hubo «unos primeros tiempos», una primera fase, la del descubrimiento y ocupación de las Indias, que por su misma índole cambiante, incierta e imprevisible, era prácticamente imposible someter a control. No se contaba todavía con una base mínimamente estable, sobre la cual pudiera levantarse una sociedad organizada. El propio Solórzano consigna este hecho con toda claridad: «Lo cual aún fue menos de maravillar en aquellos primeros tiempos de los descubrimientos y conquistas de este Nuevo Orbe, donde aún no se habían podido formar ni establecer repúblicas ni magistrados que amparasen a los indios y executasen con rigor las leyes dadas para ello, como ahora las hay; y todo se obraba y gobernaba por capitanes, soldados y marineros, gente que llevada (como es ordinario) de su ferocidad y codicia, no era mucho que traspasase las leyes humanas» ${ }^{79}$.

De esto fueron plenamente conscientes los hombres de la generación siguiente a esa primera fase con responsabilidades de gobierno o de acción apostólica que desarrollaron su labor en Indias durante la segunda mitad del siglo XVI. Las Nuevas Leyes de 1542-1543 (fruto principalmente de las ideas renovadoras de Vitoria) marcan un hito histórico y ponen en marcha un proceso de transformación de la sociedad indiana. Desde ellas, como desde una atalaya, se podía ya tomar distancia y ganar la altura suficiente para distinguir las diversas etapas del camino recorrido. Evidentemente los tiempos han cambiado. De este transcendental acontecimiento parece no haber tomado Las Casas clara conciencia: en 1566 sigue manteniendo prácticamente las mismas tesis que cincuenta años antes, como si las circunstancias continuaran siendo las mismas y nada nuevo hubiera sucedido.

\footnotetext{
78 Carta magna de los indios. Fuentes constitucionales 1534-1609 (CHP 27, 322).

79 Política indiana, lib. I, cap. 12, n. 26 (BAE 252, 125).
}

Hispania Sacra, Missionalia hispanica, 58

117, enero-junio 2006, 263-327, ISSN: 0018-215-X 
El Oidor Tomás López Medel fue especialmente sensible a este dato. En la carta, anteriormente mencionada, que escribe a los Reyes de Bohemia lamenta las injustas y falsas acusaciones que muchas veces derivan de esta confusión de tiempos «representando delante de Vuestra Alteza mil quexas y acumulándole los hurtos que hizo, los indios que mató agora hace cien años por su necesidad y defensa y porque entonces convenía por dicha hacerse, y mezclando y revolviendo los tiempos... Por descriminar el negocio, si se hicieron hurtos, si se mataron indios en un tiempo, fue ya pasado y por dicha convino entonces; pero agora ya todos son comedidos y cristianos y leales vasallos de Vuestra Alteza» ${ }^{80}$.

Pero aun los desmanes cometidos por los españoles, sobre todo en los primeros tiempos, encuentra Solórzano ciertos atenuantes en el salvajismo y barbarie de los indios, que les obligaban a actuar severamente contra ellos o les inducían a excederse en los castigos. Solórzano tiene buen cuidado de indicar que esta misma observación ya la había hecho, entre otros, José de Acosta. Y avanzando en esta línea exculpatoria ante unos hechos que «demuestran que probablemente no hay que acusarlos y abochornarlos tanto», afirma: «A menudo también, aceptados y recibidos benévolamente al principio, después atacaban insidiosamente sin causa justa. Todos estos hechos... pudieron ofrecer a los capitanes y soldados españoles legítima ocasión de hacer la guerra» ${ }^{81}$. Posteriormente lo dejaría consignado en su obra castellana Política indiana: «De más de que, miradas las cosas con ojos desapasionados, en muchas partes dieron ocasiones bastantes para ser guerreados y maltratados o ya por sus bestiales y fieras costumbres o por los graves excesos y traiciones que cometían contra los nuestros...; y en respuesta de esta misma objeción y calumnia lo advierte el Padre Acosta y otros autores» ${ }^{82}$.

Es verdad que, como dicen los acusadores, con ocasión de estas guerras y a consecuencia de las crueldades y malos tratos que recibieron de los españoles, murieron muchos indios. Pero la causa principal de la despoblación (que tanto exagera Las Casas) no fueron las guerras, «sino diversas epidemias de peste, así como terremotos y más aún sus propios vicios, sobre todo el de la borrachera, y el uso de la hierba $\operatorname{coc} a$, al que se entregaron sin medida» ${ }^{83}$. Aduce los testimonios de Pedro de Cieza, Acosta, Juan de Torquemada y algunos contemporáneos más sobre los pavorosos estragos que causaron las epidemias en Nueva España y Perú. Para demostrar la tremenda despoblación que provocó el desastre sanitario, hubiera podido encontrar el apoyo de muchísimos testigos directos o muy próximos a los hechos, que ofrecen una sorprendente coincidencia, y por tanto una base firme de objetividad histórica.

80 Tomás LóPEZ Medel, Informes y testimonios (CHP 28, 71).

81 Juan SolórZAno, De Indiarum iure, lib. III, cap. 6, n. 56 (CHP 2. a Serie 1, 395).

82 Polítoca indiana, lilb. I, cap. 12, n. 29 (BAE 252, 126).

83 Juan SolóRZAno, De Indiarum iure, lib. III, cap. 6, n. 63 (CHP 2. ${ }^{a}$ Serie 1, 397-398). 
Insisten, finalmente, los acusadores: como quiera que se pretenda explicar las cosas, nuestros reyes no quedan libres de culpa por el recurso de atribuir a la disolución y codicia de capitanes y soldados los abusos de la conquista, puesto que en último término los soberanos se hacen responsables de los excesos de sus mandatarios y están obligados a restitución. Al igual que el señor se hace responsable de los delitos de sus criados a quienes encomendó su cometido, y está obligado a reparar los daños. Los príncipes tienen la obligación de castigar y reprimir severamente a los soldados que emprenden guerras sin su autorización.

A pesar de estas razones y sofismas — responde Solórzano- nuestros reyes no son responsables de esos atropellos, porque está fuera de toda duda el exquisito cuidado que pusieron en la conversión de los indios y en el cumplimiento del encargo que les encomendó la Santa Sede. Y «ahí están los muchos y cualitativos progresos que ha logrado en estos territorios la religión cristiana», por más que en los comienzos haya podido haber algún exceso por la permisividad o altanería de los militares. Nunca los comienzos son perfectos; lo importante es que la intención y el fin del operante hayan sido rectos. Tanto más cuanto que «en los mencionados comienzos y medios empleados» hubo no pocas personas ejemplares que «iluminaron este Nuevo Mundo con sus virtudes, sus milagros y su martirio». Ya advirtió Acosta, añade Solórzano, al hablar de los abusos que fueron viciando la institución de las encomiendas, que «estas cosas ocurren por deficiencias de los hombres, no de la causa. Y la perversidad de los malos no tiene por qué desacreditar a los buenos» ${ }^{84}$.

Queda, sin embargo, todavía sin aclarar un aspecto que atañe directamente a la responsabilidad de los reyes: ¿Ha habido siempre realmente una cuidadosa selección de las personas que han pasado a las Indias con cargos de administración o de gobierno? Solórzano responde una vez más que a nuestros reyes «nada les fue tan querido desde siempre como promulgar leyes piadosas y oportunas para tales expediciones, buscar cuidadosamente a quienes fueran capaces de ejecutarlas y reprimir con la máxima severidad la escandalosa desvergüenza de los transgresores. Y si alguna vez no se la pudo poner coto, ello se ha de atribuir sin duda a la enorme distancia de las regiones, a la avaricia de la soldadesca, a la rudeza y salvajismo de los indios...» ${ }^{85}$. Son atenuantes que admiten Acosta y otras muchas personas que conocían a fondo la realidad indiana por una larga experiencia de años.

Pero esto no aclara el punto principal de la selección de personas. Acosta (a quien esta vez no cita Solórzano) no parece estar de acuerdo; más bien tiene la

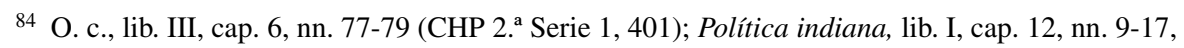
25 (BAE 252, 119-122, 125); José DE ACOSTA, De procuranda indorum salute (CHP 23, 471).

85 O. c., lib. III, cap. 6, nn. 106-107 (CHP 2. ' Serie 1, 409).

Hispania Sacra, Missionalia hispanica, 58

117, enero-junio 2006, 263-327, ISSN: 0018-215-X
} 
impresión de que no siempre se ha acertado con la designación de las personas para el desempeño de determinados cargos. Haciendo de alguna manera suyo el parecer de «un insigne varón» (probablemente Polo de Ondegardo) reproduce las palabras de un comentario suyo sobre la gran talla moral que habrían de tener los ministros reales. El comentario incluía así mismo esta dura crítica: «¿Quiénes somos los que venimos a estas tierras? Somos como la hez de España, de manera que parece que hemos arribado aquí más para alivio de ella que para hacernos cargo de estos pueblos» ${ }^{86}$.

Acosta parece reconocer, sin embargo, el punto de exageración que asoma en estas palabras, pues a renglón seguido señala que no tanto se pretende agraviar con ellas «a los muchos esclarecidos gobernantes que estas provincias han tenido y tienen, y han florecido con la gloria de un gobierno cristiano y prudente, cuanto llamar la atención más bien y plantear la dificultad que comporta la índole misma de los asuntos indianos». En ese mismo contexto de sacudida de conciencia, de llamada de atención ante un problema tan grave como es la selección de las personas parece han de interpretarse también estas palabras del propios Acosta: «Tan gran ruina de los indios somos los ministros, que debiendo ser muy selectos para esta apostólica misión de predicar a Cristo a estos gentiles, admirables en sabiduría y santidad, venimos los más despreciables sin duda y los últimos en todo» ${ }^{87}$. Es claro que no se pueden tomar estas palabras en sentido literal, porque esto sería desconocer, contra toda justicia la talla extraordinaria de destacadas personalidades (entre las que se encuentra el propio Acosta) que dejaron su impronta indeleble en la gran empresa de colonizar y evangelizar el Nuevo Mundo ${ }^{88}$.

El calor con que Solórzano defiende la actitud de la Corona y la legitimidad de los títulos que posee España tanto para ocupar como para retener las Indias no le impide al final de su obra reconocer la culpabilidad de los españoles en las injusticias y crueldades cometidas contra los indios. A todos los súbditos del rey, en mayor o menor grado, alcanza dicha culpabilidad. Solórzano reparte responsabilidades: «Y aunque es verdad que todos somos culpables de que no se hayan corregido, enmendado y castigado severa y rigurosamente estos abusos, lo son, sin embargo, sobre todo los eclesiásticos y prelados y los que han sido designados para cuidar y proteger a los indios... Ningún remedio se podrá esperar cuando la ruina arranca precisamente de donde cabía esperar la salvación ${ }^{89}$.

Pero estos graves cargos (que todavía siguen teniendo vigencia, al parecer, en la época de Solórzano) no empañan la limpia ejecutoria de los reyes en el

\footnotetext{
86 José DE AcostA, De procuranda indorum salute, lib. III, cap. 5, n. 1 (CHP 23, 413-415).

87 O. c., lib. IV, cap. 4, n. 3 (CHP 24, 31).

88 Cfr. Juan SolóRzano, De Indiarum iure, lib. III, cap. 6, nn. 77-99 (CHP 2. a Serie 1, 401); Política indiana, lib. I, cap. 12, nn. 9-17, 25 (BAE 252, 119-122, 125).

${ }^{89}$ O. c., lib. III, cap. 8, nn. 26-27 (CHP 2. ${ }^{\text {a Serie } 1,479) .}$
} 
gobierno de las Indias, desde sus comienzos, ni invalida los derechos que les asisten a la ocupación y retención de aquellas provincias. Son los enviados a las Indias (cualquiera que sea su condición social o el cometido que se les encomiende) los que tienen como primera tarea de urgencia trabajar ininterrumpidamente en las transformación de la sociedad indiana con el ejemplo de una vida intachable, la instrucción religiosa y la promoción de la justicia. Por eso termina Solórzano su estudio sobre los títulos exhortando ante todo a los gobernantes y prelados «a que vigilen diligentemente sobre la grey que se les ha confiado y a que previsoramente salgan al paso de los mencionados agravios, fraudes y delitos que conturban y afligen a los indios, indagando dónde se asienta el veneno, sajando con hierro e incluso con fuego, si lo juzgaren necesario, porque cuando la llega es mortal y profunda, una medicación severa es más segura» ${ }^{90}$.

\section{JUSTICIA DE LA ADMINISTRACIÓN Y GOBERNACIÓN DE LAS INDIAS}

Solórzano da un paso más en la defensa de la Corona. Los títulos justos que avalan las retención de las Indias y la permanencia de España en ellas podría quedar en entredicho, si su administración y gobernación no se ejecutase a derecho. Por eso era necesario traer a examen las principales instituciones sobre las que estaba montada la vida social en las Indias y ver si, a pesar de las injusticias repetidas veces denunciadas, las autoridades responsables buscaban el remedio, corregían abusos y promovían la justicia. ¿Funcionaba de hecho la vida social sobre bases de justicia, igualdad y respeto, o estaba más bien toda ella organizada desde una gigantesca explotación del indio para beneficio y enriquecimiento exclusivo de los españoles? En esa dirección iban las acusaciones y denuncias.

\section{La institución de las encomiendas}

Entre todas las instituciones sociales había una especialmente controvertida y de una importancia transcendental para el buen desenvolvimiento de la sociedad indiana: la institución de las encomiendas. El problema era tan serio, que Solórzano dedica a su examen nada menos que todo el libro tercero con sus treinta y dos capítulos de su obra Política indiana. Toda su línea de argumentación en materia tan delicada y discutida se ajusta plenamente en los puntos principales a los planteamientos de la mayor parte de todas aquellas personalidades, formadas en la Universidad de Salamanca, que fueron expresamente consultadas para el caso o de catedráticos que estudiaron a fondo el tema; tal es

\footnotetext{
90 O. c., lib. III, cap. 8, nn. 28-29 (CHP 2. ${ }^{\text {a Serie, } 49) .}$
} 
el caso de José de Acosta en Lima y Juan de Zapata y Sandoval en México, a quienes Solórzano sigue y cita profusamente.

La discrepancias en esta cuestión con Bartolomé de las Casas, para quien las encomiendas en sí mismas consideradas son intrínsecamente malas, es total. Al apasionado obispo de Chiapa le faltó seguramente serenidad de espíritu y por ende de profundidad en el tratamiento de tema tan importante. Empezó por no distinguir dos tipos de encomiendas: las que se dieron en los primeros tiempos de la conquista y las que definitivamente se establecieron y se aprobaron por ley tras un proceso de transformación y de reformas radicales.

No se podía dudar que los primero repartimientos de indios derivaron en graves perjuicios para éstos y para su libertad por el egoísmo y la codicia de los encomenderos que «atendiendo más a su provecho y ganancia — dice Solórzano- que a la salud espiritual y temporal de ellos, no había trabajo en que no les pusiesen, y los fatigaban más que a las bestias, como lo refiere y encarece en un particular tratado que de esto hizo el obispo de Chiapa» ${ }^{91}$. El Emperador, tan pronto como tuvo noticia de los abusos que se introdujeron en estas primeras encomiendas, hechas las pertinentes consultas «a los del Consejo y a teólogos religiosos y personas de muchas letras y de buena y santa vida», las prohibió.

$\mathrm{Y}$ estas son las encomiendas contra las que escribió Las Casas, «con que tanto nos dan en rostro» los enemigos de nuestra nación. «Pero en las segundas, como hoy se practican, cesa todo lo que él lamenta y opone, pues lo indios no quedan por esclavos ni aun por vasallos de los encomenderos, y sólo reconocen al rey por señor, como los demás españoles». Y por los tributos que perciben quedan los encomenderos obligados, bajo juramento, a procurar con toda justicia el bienestar temporal y espiritual de sus encomendados. «Y haciéndolo así, como están obligados, ya se ve que no se pueden hallar ni halla dureza ni injusticia alguna en estas encomiendas» ${ }^{92}$.

Este nuevo modelo de encomienda reformada, que parecen ignorar Las Casas y sus más inmediatos seguidores, se asentó definitivamente, cuando en 1546 se revocó la ordenanza XXX de las Nuevas Leyes, que prohibían las encomiendas, tras una amplia consulta a los Consejeros de Indias y del Estado. La mayor parte de los consultados coincidían en los siguientes puntos: las encomiendas son en sí buenas; es conveniente que se repartan los pueblos de indios remunerando, incluso con largueza, a los conquistadores en proporción a los servicios prestados y a la calidad de las personas; las encomiendas han de ser perpetuas, sin jurisdicción civil ni criminal (algunos señalan que sólo con jurisdicción civil) quedando en manos del rey sólo «las cabeceras principales de la tierra y

\footnotetext{
91 Se refiere, claro está, a la obra de Bartolomé DE LAS CASAS, Brevísima relación de la destruición de las Indias (Sevilla, 1552).

92 Juan SolóRZANo, Política indiana, lib. III, cap. 1, nn. 8-16, 23 (BAE 253, 7-9).
} 
puertos del mar»; la perpetuidad de las encomiendas ayudará a que los encomenderos se olviden de Castilla y se arraiguen en la tierra ${ }^{93}$.

Esta doctrina de las encomiendas así reformadas es la que se impuso de manera generalizada entre teólogos y juristas hasta hacerse tradicional, y así llegó hasta Solórzano. Alfonso de Castro, en clara alusión a Las Casas, dirá en su informe 1554 que pretender quitar las encomiendas porque se han cometido abusos, es «celo indiscreto». Juan de Matienzo, en su informe al Consejo de Indias en 1562, concluirá que, si el encomendero es buen cristiano, bien se le puede encomendar indios; «y decir que esto es intrínsecamente malo es ajeno a toda razón».

Apoyándose en esta tradición de la Escuela de Salamanca, Solórzano justifica las nuevas encomiendas con las tres mismas razones (si bien no expuestas en el mismo orden) con las que lo hizo Acosta ${ }^{94}$. En primer lugar, porque todos los encomenderos quedan obligados a cuidar de la doctrina y defensa de los indios. $\mathrm{Y}$ «¿qué cosa se puede pensar más razonable, más saludable que encomendar los nuevos cristianos a la diligencia de los antiguos?» La segunda razón es la imposibilidad de conservar el Nuevo Mundo, «si no lo guardaran los mismos que lo descubrieron, con el fin de refrenar las licencias de los indios, defenderlos de sus comarcanos e irlos acostumbrando a nuestras leyes». La tercera razón que justifica las encomiendas es la obligación que tienen los reyes de premiar a tantos capitanes, soldados y hombres beneméritos, por haberles servido en aquellas conquistas y poblaciones, gastando sus vidas y hacienda sin paga alguna. Solórzano recuerda que, precisamente basado en esta razón, el criollo y catedrático de México, el agustino Juan de Zapata y Sandoval, escribe en 1609 que las encomiendas se han de admitir no sólo por justicia distributiva en atención a los méritos de los conquistadores, sino también por justicia conmutativa como estipendio a sus grandes trabajos ${ }^{95}$.

De estas tres causas justificativas, tomadas de Acosta, concluye Solórzano que se ha llegado a un concepto nuevo de encomienda lícito y justo, a resguardo de las acusaciones lanzadas por Las Casas. Asentada esa base, ensaya una definición de la nueva encomienda: «Derecho concedido por merced real a los beneméritos de las Indias para percibir y cobrar para sí los tributos de los indios que se le encomendaren por su vida y la de un heredero, conforme a la ley de sucesión, con cargo de cuidar del bien de los indios en lo espiritual y temporal, y de habitar y defender las provincias donde fueren encomendados y hacer cumplir todo esto, homenaje o juramente particular» ${ }^{96}$.

93 Cfr. CHP 27, 215-255.

94 José DE ACOSTA, De procuranda indorum salute, lib. III, cap. 11, nn. 1-3 (CHP 23, 459-471).

95 Juan SolóRZAno, Política indiana, lib. III, cap. 2, nn. 11-15 (BAE 253, 15-16); Juan DE ZAPATA Y SANDOVAL, De iustitia distributiva et acceptione personaum ei opposita, I parte, cap. 4 (Vallisoleti, 1609, p. 46).

96 Juan Solórzano, Política indiana, lib. III, cap. 3, n. 1 (BAE 253, 21-22).

Hispania Sacra, Missionalia hispanica, 58

117, enero-junio 2006, 263-327, ISSN: 0018-215-X 
El concepto ha cambiado esencialmente: Lo que caracterizaba las primeras encomiendas era el repartimiento que hacían de los indios los descubridores y pobladores para su servicio y trabajo, «así para sus casas como para la busca y saca de oro y plata, labor de los campos, guarda de los ganados y otros ministerios» ${ }^{97}$.

De acuerdo con esta detallada definición insiste Solórzano con gran encarecimiento, siguiendo de cerca de José de Acosta, en quien principalmente se inspira, en una obligación de primera importancia en la que incurren los encomenderos al recibir la encomienda, y es que sean para los indios «unos como patronos o protectores verdaderos patronos o defensores que los recibiesen debaxo de su amparo y defensa y procurasen su enseñanza espiritual y política» ${ }^{98}$. Si no cumplen con esta obligación, manda expresamente la cédula real de 7 de junio de 1555 que sean «obligados a restituir lo que llevan, y es legítima causa para les privar de las encomiendas. Pero si cumplen con ella, pueden llevar los tributos con buena conciencia» ${ }^{99}$.

Tal es también la opinión de Acosta. De estos principios infiere que «deben procurar mucho los que los nombran y proveen, que sean personas de vida y conciencia aprobada y tales como se requieren para mirar por la de los otros», como enseña «con graves y encarecidas palabras» el Padre José de Acosta ${ }^{100}$. Consciente de la importancia de la obligación lanza estas palabras de sinceración: «Siempre desearé mucho que entiendan y se persuadan los encomenderos que este beneficio de las encomiendas se les da por el oficio... de procurar el bien de sus indios y que el derecho ordena que quien menosprecia éste, pierde aquél» ${ }^{101}$.

Por tanto, no pueden en conciencia pedir ni recibir de los indios más tributos de los que están tasados como retribución al oficio que se les confía. «Y así, ni les podrán pedir obras rústicas ni otro género alguno de servicios personales, ni muchachos para que sirvan a sus mujeres de coser, texer, labrar o guisar, ni gallinas, huevos ni otras cosas tales para su comida» ${ }^{102}$.

La consecuencia es que están obligados en conciencia a restituir todo lo mal llevado; principio que deben tener presente los confesores. La manera de llevar a la práctica la restitución está ya determinada por los teólogos: en propia mano a los mismos perjudicados, si se hallan, o a sus hijos y herederos. «Pero si no se hallaren o fuere dificultoso de averiguar quiénes fueron los damnificados (lo cual es lo más ordinario), les han de aconsejar los confesores que repartan o que manden la cantidad en que sintieren gravada su conciencia a las comunidades,

97 O. c., lib. III, cap. 3, n. 1; cap. 1, n. 3 (BAE 253, 6).

98 O. c., lib. III, cap. 26, n. 1 (BAE 253, 300).

99 O. c., lib. III, cap. 26, n. 3 (BAE 253, 300)..

100 O. c., lib. III, cap. 26, n. 17 (BAE 253, 303).

101 O. c., lib. III, cap. 26, n. 20 (BAE 253, 304).

102 O. c., lib. III, cap. 26, n.40 (BAE 253, 309). 
iglesias u hospitales de los mismos indios o a otras obras pías que redunden en común utilidad espiritual o temporal de todos ellos». Que esto no quedaba en una mera formulación de palabras, sino que realmente la restitución se llevaba a efecto, nos lo asegura seguidamente el mismo Solórzano invocando su propia experiencia: «Y así vi que lo hicieron muchos estando yo en el Perú y fui juez de algunos pleitos sobre estos legados» ${ }^{103}$.

\section{Los tributos}

El problema de las encomiendas lleva inevitablemente a otro de los grandes temas que repercuten de una manera directa en la justicia de la administración y gobierno de las Indias: el tema de los tributos. Una tributación injusta puede convertir en tiránico a un gobierno. Que hubo abusos en la extracción de los tributos consta por numerosos testimonios e informes. Dieron base estos abusos para poner en entredicho la justicia de la administración y gobierno de los reyes en Indias? ¿Cuál es la opinión de Solórzano sobre esta cuestión? También en este punto importante permanece fiel a la doctrina teológico-jurídica de la Escuela de Salamanca siguiendo de cerca especialmente a autores como Acosta, Zapata o Matienzo, que estudiaron a fondo el problema desde la misma realidad indiana vivida.

Por de pronto hay un punto de partida que nadie pone en duda: es justa una tributación como contraprestación por la obra que España realiza en las Indias, sean los reyes los dueños absolutos de ellas, «como lo son», o meros administradores en orden a la cristianización e instrucción de los indios. Y esto nadie lo puede poner en duda. Zapata expresamente da por supuesto «que los individuos y miembros de una comunidad, al igual que participan de los bienes comunes, han de contribuir también proporcionalmente a las cargas indispensables para la conservación del bien común» ${ }^{104}$. Acosta da también por cosa evidente que los españoles pueden exigir tributos a los indios. «Pero cuántos y cuáles, de qué tipo y con qué limitaciones se han de exigir, es sin duda muy oscuro y difícil de explicar cuidadosamente» ${ }^{105}$.

Siguiendo los principios generales de Acosta, dirá Solórzano que los tributos que se exijan a los indios han de ser muy moderados y hay que cobrarlos «con toda suavidad y templanza, principalmente considerada su tenuidad y pobreza» ${ }^{106}$. Y a esta meta precisamente apuntan muchas cédulas reales que mencionan elogio-

103 O. c., lib. III, cap. 26, n. 46 (BAE 253, 311).

104 Juan DE ZAPATA Y SANDOVAL, De iustitia distributiva et acceptione personarum ei opposita (CHP 27, 99); Juan SolóRZANO, Política indiana, lib. II, cap. 19, nn. 2, 8-9.

105 José DE Acosta, De procuranda indorum salute, lib. III, cap. 7, n. 1 (CHP 23, 429).

106 Juan SolórZANo, Política indiana, lib. II, cap. 19, n. 24 (BAE 252, 319). 
samente tanto Solórzano como Acosta. De ellas dice Acosta: «Leyes tan dignas y cristianas hay que alabarlas con toda justicia» ${ }^{107}$.

Otra cosa serán los abusos que en casos contados se hayan podido cometer en contra de las mismas. Pero Solórzano hace bien notar (por lo demás también lo recuerda Acosta ${ }^{108}$ ) cómo en ellas se manda que «sea mucho menor la carga que la que pagaban en su infidelidad y que vaya con lectura o advertencia de que queden antes ricos que pobres, con lo necesario y aun sobrado para su sustento y el de sus familias y otras necesidades de la vida humana, y para curarse en sus enfermedades» ${ }^{109}$.

Es más, hubo un claro empeño por parte de los gobernantes de Indias en llevar a efecto la justicia de estas leyes. Aceptando el testimonio de Acosta, que fue testigo directo, Solórzano afirma: «Esta moderación y tasa se encargó últimamente en las provincias del Perú al Virrey Don Francisco de Toledo, que las anduvo y visitó todas personalmente para el efecto y las dexó hechas con gran suavidad, equidad y destreza» ${ }^{110}$.

Las claras directrices marcadas por las leyes dejan sin validez y sin base alguna racional la excusa, utilizada por algunos, de que los indios son por su natural muy dados a la ociosidad, y por tanto «se les podían y debían cargar muchos mayores tributos» ${ }^{111}$; puesto que la regla que se ha de tener siempre presente es la de «no exceder de los fines y necesidades para que se cargan» ${ }^{112}$; todo lo que exceda es robo.

En este mismo sentido había enseñado Acosta que para salvar la justicia de los impuestos no basta con que el contribuyente los pueda pagar: «es necesario que pueda y además que deba pagar. La exacción será igualmente injusta tanto si no puede como si no debe pagar» ${ }^{113}$.

Precisamente apoyado en estos principios Juan de Zapata y Sandoval (a quien expresamente cita Solórzano) denuncia como injusto el tributo que se impuso en su tiempo a los indios de Nueva España añadido al anterior: «Así mismo, para el sustento suficiente de la comunidad se les quita uno de aquellos cuatro reales [es decir, el tostón] y en su lugar cada uno contribuye con una gallina; de manera que este es el tributo que se ha añadido al antiguo; Tres reales para el rey, una gallina para que abunden y medio real para los jueces ${ }^{114}$.

107 José DE AcostA, De procuranda indorum salute, lib. III, cap. 8, n. 2 (CHP 23, 439).

108 José DE Acosta, De procuranda indorum salute, lib. III, cap. 8, n. 3 (CHP 23, 441).

109 Juan Solórzano, Política indiana, lib. III, cap. 19, n. 28 (BAE 252, 320).

110 Juan Solórzano, Política indiana, lib. III, cap. 19, n. 30 (BAE 252, 320).

111 Juan Solórzano, Política indiana, lib. II, cap. 19, n. 34 (BAE 252, 321).

112 Juan Solórzano, Política indiana, lib. II, cap. 19, n. 34 (BAE 252, 321).

113 José DE Acosta, De procuranda indorum salute, lib. III, cap. 8, n. (CHP 23, 441).

114 Juan DE ZAPATA Y SANDOVAL, De iustitia distributiva et acceptione personarum ei opposita (CHP 27, 111). 
En definitiva, a pesar de los fallos que en casos concretos se hayan podido observar, Solórzano no duda de la justicia sistema fiscal tal como ha sido regulado por las leyes de la Corona. La conclusión es tajante: «De manera que siempre ha ido nuestros católicos y piadoso reyes en esta parte con la atención que piden sus obligaciones, sin peligro de caer en los pecados, excomuniones y cargos de restitución que la común Escuela de teólogos y juristas dice que incurren los que cargan a sus vasallos tributos injustos o demasiados» ${ }^{115}$.

El sentido de la justicia pide también (y así se manda por las leyes) que en determinados casos haya exención de tributos. Así, están exentos los enfermos que se sientan impedidos de poder trabajar. Es así mismo causa de exención una notoria pobreza o una gran esterilidad en los frutos y especies en que estuvieren tasados los tributos o una grave peste. Así lo resuelve también el Padre José de Acosta, «que es de los que mejor entendieron las materias de los indios e Indias, diciendo que la remisión... no se puede ni debe cobrar de ellos en años sucesivos» ${ }^{116}$.

En efecto, Acosta examina algunos casos en los que exigir el tributo sería una grave injusticia. Entre ellos enumera una mala cosecha o una enfermedad o un incendio en la vivienda o la muerte de las ovejas por sarna. «Además, como se ha señalado antes, de ninguna manera ha de tributar sino de aquello que tiene o puede tener cómodamente, después de reservar para sí y su familia el congruente sustento. Y si lo pierde por cualquier desgracia, no se le ha de molestar en apremiarle ni se le debe agravar en los años siguientes por el tributo que ahora no puede pagar» ${ }^{117}$.

\section{Los servicios personales}

Muy espinoso y nunca del todo aclarado fue el complejo problema de los llamados «servicios personales», que con demasiada frecuencia se convertían en instrumento de injusticia y de explotación inicua de los indios. Solórzano lo estudia con detención y muestra cómo, desde las instancias de gobierno y en consonancia con la doctrina de los teólogos y juristas más eminentes, se buscó en todo momento una solución justa que corrigiera los desórdenes que subrepticiamente se iban introduciendo en la sociedad indiana especialmente a través de los encomenderos.

Siguiendo, como siempre los pasos de José de Acosta ensaya una definición de lo que se entendía por servicios personales: «Se comprenden generalmente

\footnotetext{
115 Juan Solórzano, Política indiana, lib. II, cap. 19, n. 31 (BAE 252, 320).

116 Juan SolóRzAno, Política indiana, lib. II, cap. 20, nn. 19, 22, 27, 32-33, 38 (BAE 252, 331334).

117 José DE Acosta, De procuranda indorum salute, lib. III, cap. 16, n. 2 (CHP 23, 501-502).
}

Hispania Sacra, Missionalia hispanica, 58

117, enero-junio 2006, 263-327, ISSN: 0018-215-X 
cualesquiera aprovechamientos que pretendemos sacar del trabajo, obra y servicio de ellos [los indios] para la labranza o crianza, edificios de casas, labores de minas, cargas, trajines, obrajes y otros ministerios públicos o domésticos. Y más en particular el apremio y sujeción en que pretenden ponerlos y tenerlos sus encomenderos, sirviéndose de ellos a toda su voluntad y contra la de los indios» ${ }^{118}$.

Este tipo de servicio personal, introducido por los encomenderos, «que es injusto e indigno de permitirse», fue siempre prohibido «con grande solicitud y cuidado» por nuestros reyes a través especialmente de las Nuevas Leyes y otras muchas cédulas y ordenanzas reales que con insistencia se van repitiendo en el correr de los años; porque «es opresión y quebrantamiento de la libertad natural» ${ }^{119}$. En este caos la prescripción «no puede valer ni alegarse, por ser corruptela», siempre prohibida ${ }^{120}$. Y aunque fuera en sí justa, como opina Matienzo, la permutación de este tipo de servicio al encomendero por el tributo en determinadas circunstancias, sin embargo, es casi imposible en la práctica la ejecución de unas condiciones justas por la «soberbia, dureza y codicia de los encomenderos», como da la experiencia ${ }^{121}$.

Además del servicio a los encomenderos, que acabamos de describir, existe otra clase de servicio personal llamado de los «mitayos», que consiste en llevar a los españoles «agua o leña o cuidar de sus cocinas y caballerizas..., aunque no quieran, y pagándoles un corto jornal» ${ }^{122}$.

Matienzo y Acosta no lo creen injusto, si se guardan ciertas condiciones ${ }^{123}$; pero siempre se ha prohibido «por la dificultad que hay en que se ajusten bien en la práctica de los temperamentos de estos autores» ${ }^{124}$. Este servicio sólo podrá justificarse, si se acepta voluntariamente y se ofrece una buena paga y mejor tratamiento, como advierten algunas cédulas. Son los mismos españoles los que han de hermanarse entre sí, sirviéndose mutuamente, «pues no puede consentirse que todos puedan ser iguales y caballeros en pasando a aquellas tierras» ${ }^{125}$. En cualquier caso, pesa más la libertad de los indios «y nunca el derecho natural ni civil ha querido permitir ni permite que nadie busque ni consiga comodidades y aprovechamientos particulares suyos con trabajos forzados y violentadas descomodidades de otros» ${ }^{126}$.

118 Juan SolórZano, Política indiana, lib. II, cap. 2, n. 1 (BAE 252, 141)

119 Juan Solórzano, Política indiana, lib. II, cap. 2, n. 4 (BAE 252, 142).

120 Juan Solórzano, Política indiana, lib. II, cap. 2, n. 19 (BAE 252, 145).

121 Juan Solórzano, Política indiana, lib. II, cap. 2, n. 21 (BAE 252, 146).

122 Juan SolóRzAno, Política indiana, lib. II, cap. 3, n. 1 (BAE 252, 147).

123 Juan Solórzano, Política indiana, lib. II, cap. 3, n. 2 (BAE 252, 147-148).

124 Juan Solórzano, Política indiana, lib. II, cap. 3, n. 3 /BAE 252, 148).

125 Juan Solórzano, Política indiana, lib. II, cap. 3, n. 11 (BAE 252, 150).

126 Juan Solórzano, Polític indiana, lib. II, cap. 3, n. 13 (BAE 252, 150). 
Existe, finalmente, en algunas provincias otra especie de servicio personal para exclusiva comodidad de los españoles. Se trata generalmente de indios que, «huidos de sus naturales asientos», se habían asentado en casas de españoles y en sus heredades o chácaras, para servirles en ellas a cambio de doctrinarlos, vestirlos y darles conveniente salario, «y a veces algunos pedazos de tierra que los labrasen por su cuenta y para su mismo sustento» ${ }^{127}$. Con lo cual adquirían un cierto derecho sobre ellos y su familia; quedaban adscritos a sus casas sin poder ausentarse de ellas. De ahí el nombre de yanaconas (=de servicio) que se les puso, o de naboríos en Nueva España ${ }^{128}$.

No aparece clara ni la justicia ni la injusticia de este servicio. Por una parte, Matienzo lo aprueba y lo tiene por muy conveniente; piensa que no atenta contra la libertad, «pues libre y voluntariamente se agregaron a estas haciendas y libres están y permanecen en ellas, dueños de sí» ${ }^{129}$. También el Virrey Toledo lo cree conveniente e incluso necesario «para el bien del reino y de los mismos indios» ${ }^{130}$, con tal de que se les pague bien sus salarios y «vayan de su voluntad a las chácaras que quisieren y no sean detenidos en ellas con fuerza con paga o sin ella» ${ }^{131}$.

Solórzano preferiría que se quitara del todo este servicio por las muchas ocasiones de abuso que en él se dan, según le enseñaba la experiencia. Las utilidades que de él pueden derivarse para los indios, dice Solórzano, «las tengo por poco ciertas y los daños por superiores» ${ }^{132}$. Cuál fuera la solución más acertada fue cuestión discutida. Pero lo que queda en claro es que el problema se estudió con seriedad y profundidad, tratando de eliminar cualquier aspecto que pudiera atentar contra la justicia y la libertad de los indios, y que tal era también el espíritu de la legislación.

Dentro del concepto global de servicios personales entran también aquellos servicios que por considerarse de utilidad pública, contribuyen al bien común de la comunidad como tal, y por tanto a un crecimiento de bienestar así de indios como de españoles. ¿Se puede obligar justamente a los indios a estos servicios de utilidad común? La respuesta está ligada, ya de entrada, a un principio fundamental: puesto que los indios son de naturaleza libres, como los mismos españoles, e iguales a ellos, han de ser tratados como los demás vasallos de España ${ }^{133}$. Por consiguiente, no se ha de gravar en semejantes servicios más a los indios que a los españoles, negros, mestizos y mulatos; antes menos, porque los

\footnotetext{
127 Juan Solórzano, Política indiana, lib. II, cap. 4, n. 1 (BAE 252, 152).

128 Juan Solórzano, Política indiana, lib. II, cap. 4, n. 3 (BAE 252, 152).

129 Juan Solórzano, Política indiana, lib. II, cap. 4, n. 9 (BAE 252, 153-154).

130 Juan Solórzano, Política indiana, lib. II, cap. 4, n. 18 (BAE 252, 155).

131 Juan Solórzano, Política indiana, lib. II, cap. 4, 19 (BAE 252, 155).

132 Juan Solórzano, Política indiana, lib. II, cap. 4, n. 29 (BAE 252, 158).

133 Juan Solórzano, Política indiana, lib. II, cap. 5, n. 7 (BAE 252, 162).
} 
que menos se aprovechan de ellos y «menos participan de las casas, heredades, minas, viñas, obrajes de paño, guardas de ganados y de los demás servicios y ministerios, a que comúnmente suelen ser repartidos, llevándose todo lo que resulta de ellos y sus ganancias los españoles...» ${ }^{134}$.

Las leyes mandan que se repartan entre todos por igual y no sólo entre los indios, porque es la mayor injusticia enriquecerse con el sudor ajeno ${ }^{135}$. Tal reparto equitativo es justo, una vez que «las dos repúblicas de los españoles y de los indios... se hallan muy unidas y hacen un cuerpo en estas provincias» ${ }^{136}$. Y toda república bien ordenada postula un justo reparto de los diferentes oficios, ministerios y ocupaciones, ayudándose mutuamente y ocupando cada cual su puesto según su capacidad, para el ordenamiento común y buena marcha de la sociedad; de lo contrario, no puede conservarse la vida humana ${ }^{137}$. Tal es también el parecer de Acosta, para quien la opinión contraria tiene tantas dificultades en llevarse a la práctica, que no se halla otra más absurda ${ }^{138}$.

Si en estos servicios se guarda la moderación que se debe, el resultado redundará últimamente en bien de los indios, aun cuando ocasionalmente se sigan algunos daños. Aquí «tiene lugar el adagio que dice: Que no es mal el que se compensa con mayor bien ${ }^{139}$. En cualquier cosa, por sagrada que sea, se mezclan algunos daños e inconvenientes. En teoría lo mejor sería que los indios asumieran estos servicios de utilidad común voluntariamente. Sin embargo, la experiencia ha demostrado que es necesaria alguna compulsión, porque, de lo contrario, nunca se cumplirían, por crecidos que fueran los jornales: los indios son poco amigos de trabajar, no tienen codicia, se contentan con poco, no se acuerdan de que hay un mañana; además, no hay tantos españoles para tantos servicios como se necesitan. Por lo tanto, obligarlos a estos servicios no quebranta su libertad, cuando hay una causa justa y así lo pide el bien común ${ }^{140}$.

Supuestas estas razones que avalan la conveniencia e incluso la necesidad de que existan en las comunidades indianas estos servicios de utilidad común para españoles e indios, Solórzano enumera de una manera orgánica todas aquellas condiciones que se han de guardar, «sin las cuales se podrá defender mal su justificación y conservación» ${ }^{141}$. Y estas condiciones son las siguientes:

La primera, que no cargue siempre el trabajo sobre unos mismos indios, sino que se turnen por año, meses o semanas, «como la calidad del servicio lo per-

\footnotetext{
134 Juan SolóRzano, Política indiana, lib. II, cap. 5, n. 10 (BAE 252, 163).

135 Juan Solórzano, Política indiana, lib. II, cap. 5, n. 18 (BAE 252, 165).

136 Juan Solórzano, Política indiana, lib. II, cap. 6, n. 1 (BAE 252, 170).

137 Juan SolóRZAno, Política indiana, lib. II, cap. 6, n. 5 (BAE 252, 170-171).

138 José de ACOSTA, De procuranda indorum salute, lib. III, cap. 17, n. 6 (CHP 23, 515, 517).

139 Juan Solórzano, Política indiana, lib. II, cap. 6, n. 28 (BAE 252, 175).

140 Juan SolóRzAno, Política indiana, lib. II, cap. 6, nn. 32-33, 36, 41-44 (BAE 252, 176-179).

141 Juan Solórzano, Política indiana, lib. II, cap. 7, n. 1 (BAE 252, 184).
} 
mite» ${ }^{142}$. También José de Acosta exige la condición de que se cumplan «turnos justos de trabajo entre ellos, no sea que (como dijo el Apóstol) la tolerancia de unos sea tribulación de otros, sino que se trate a todos por igual» ${ }^{143}$.

La segunda condición es que el trabajo repartido sea para sólo obras necesarias y útiles a todo el reino, «sin fatigarlos, atarearlos ni trabajarlos en ellas demasiadamente, sino en los tiempos y horas señaladas y dejándoles para su descanso las que convengan»; ni se permita en las minas trabajar de noche, como ordenan las cédulas reales, «si no es en unm caso de inminente aprieto y necesi$\operatorname{dad} \gg^{144}$.

La tercera condición es que «les quede tiempo para mirar y acudir a sus necesidades... y obligaciones que requiere su sustento y el de sus mujeres, hijos y familia y a las de los pueblos o reducciones a las que están agregados..., porque la caridad bien ordenada empieza por nosotros mismos» ${ }^{145}$.

La cuarta condición es que las personas que se manden «tengan fuerzas para sufrir y llevar los servicios y trabajos a que se aplican. Y por esto las leyes del derecho común eximían de ellos a los niños y mozos que aún no tuviesen diez y ocho años que llamaban pubertad plena». Y de ningún modo se envíe a menores de catorce años, ni tampoco a mujeres, ancianos y enfermos ${ }^{146}$.

La quinta condición es que no sean llevados muy lejos de sus pueblos y reducciones, sobre todo «a temples diversos o contrarios a su salud, complexión y naturaleza ${ }^{147}$. Porque la experiencia muestra los daños, enfermedades y muertes que de estas mudanzas de temples y lugares en que nacimos y nos criamos suelen resultar y resultan y lo que puede y obra el amor de ellos y de la patria; de forma que en muchas enfermedades no se halla otro remedio que volver a gozar de los aires de ella» ${ }^{148}$. Acosta, aducido por Solórzano, se hace cargo de esta condición, cuando habla del trabajo en minas, con estas palabras: «Para mirar por su salud, que no se traslade a quienes están acostumbrados a climas muy contrarios, ni se los haga venir de distancias muy remotas ni se los oprima con trabajos inmoderados» ${ }^{149}$.

La sexta condición es que se les pague un salario justo, en propia mano, sin tardanza y sin fraude, «porque esto lo pide y requiere también por preciso en semejantes cosas el derecho común, queriendo que aun la paga se haga todos

\footnotetext{
142 Juan SolóRZAno, Política indiana, lib. II, cap. 7, n. 2 (BAE 252, 184)

143 José DE Acosta, De procuranda indorum salute, lib. III, cap. 17, n. 6 (CHP 23, 517).

144 Juan Solórzano, Política indiana, lib. II, cap. 7, nn. 9, 17-21 (BAE 252, 186-187).

145 Juan Solórzano, Política indiana, lib. II, cap. 7, nn. 23-24 (BAE 252, 188).

146 Juan Solórzano, Política indiana, lib. II, cap. 7, nn. 33-38 (BAE 252, 189-190).

147 Juan Solórzano, Política indiana, lib. II, cap. 7, nn. 39, 41 (BAE 252, 191).

148 Juan SolóRZAno, Política indiana, lib. II, cap. 7, n. 42 (BAE 252, 191).

149 José DE Acosta, De procuranda indorum salute, lib. III, cap. 18, n. 5 (BAE 252, 535).
} 
los días» ${ }^{150}$. El precio de este salario ha de estar determinado por la ley (según afirma Acosta), como sucede en la mayoría de los casos; y si la ley faltara, por el prudente juicio de los entendidos o el mutuo acuerdo de las partes. «En todo esto - denuncia Acosta- pecan mucho y muchas veces los encomenderos y los corregidores e incluso los doctrineros» ${ }^{151}$.

La séptima condición es que especialmente los que trabajan en minas hallen en ellas a precios justos y moderados todo lo necesario para su sustento y que, como manda la cédula de 1601, «se tenga muy particular cuidado de su salud y buen tratamiento espiritual y temporal y que los enfermos sean muy bien curados». La de 1609 encarga especialmente «la buena y cuidadosa cura de los enfermos que adolecieren en la ocupación de las labores referidas, ora sean de mita o repartimiento o voluntarios, para que tengan el socorro de medicinas y los regalos necesarios» ${ }^{152}$.

Parece resonar aquí el programa de asistencia social elaborado por Acosta para los trabajadores en minas: «Que no falten ministros para su formación religiosa. Haya quien les diga misa, quien les instruya en los rudimentos de la fe, quien los confiese a la hora de la muerte y les administre los demás sacramentos necesarios. Téngase además cuidado de su salud... Suminístrese a los sanos los alimentos convenientes y no falten a los enfermos los regalos necesarios» ${ }^{153}$.

La octava condición es que se les emplee sólo en los servicios públicos y en las urgentes necesidades del rey y del reino. En consecuencia, «no se permita que los particulares ocupen los indios, que para tales ministerios se les repartieren, en otros de sólo aprovechamiento suyo o en servicios domésticos... o ganados propios en que ocuparlos y trabajarlos...» ${ }^{154}$.

La novena condición es que no reciban daño ni estorbo en la doctrina de la fe ni se les haga trabajar en días festivos en cosas serviles; «porque este cuidado es el que entre todas tiene primer lugar, y en menospreciándole ningunas pueden lograrse» ${ }^{155}$.

Como síntesis de todo este plan de protección al trabajador en los servicios de utilidad pública, sobre todo en las minas, recuerda Solórzano la cédula 1589, según la cual se ha de proceder de suerte que «no se les siga daño en su salud, y teniendo doctrina y justicia que los ampare y comida con que se sustenten y buena paga de sus jornales y hospital donde se curen, y sean bien tratados y re-

150 Juan SolóRZANo, Política indiana, lib. II, cap. 7, n. 52 (BAE, 252, 192-193).

151 Juan SolóRZAno, Política indiana, lib. II, cap. 7, n. 44 (/BAE 252, 191-192).

152 Juan Solórzano, Política indiana, lib. II, cap. 7, n. 63 (BAE 252, 195).

153 José DE Acosta, De procuranda indorum salute, lib. III, cap. 18, n. 5 (BAE 252, 535-537).

154 Juan SolórZANo, Política indiana, lib. II, cap. 7, n. 64 (BAE 252, 195).

155 Juan Solórzano, Política indiana, lib. II, cap. 7, n. 65 (BAE 252, 195-196). 
galados los que enfermaren. Y que esto se a costa de los mineros, pues resulta en su beneficio el repartirse los dichos indios» ${ }^{156}$.

Estos son los principios que han de regular y justificar todos aquellos servicios que son necesarios y redundan en el bien común de la república. Entre ellos indudablemente han de encontrarse también las obras y edificios públicos: fuentes, puentes, puertos, reparos de caminos, vías de comunicación. Y «no es mucho ni nuevo que sean compelidos a semejante trabajos los indios, pues la razón política... no permite que nadie, por privilegiado que sea, se excuse de contribuir y ayudar en tales fábricas y reparos» ${ }^{157}$. Así mismo, las labores del campo, «sin las cuales no puede sustentarse la vida humana» ${ }^{158}$. Y la cédula de 1601 dice claramente que «de esto depende la conservación de estas provincias; y porque lo contrario sería en destrucción de ellas y de los mismos indios y no poderse sustentar a sí y a sus mujeres» ${ }^{159}$. Estas labores agrarias se han de extender incluso a los viñedos. Como algunos piensan, aunque no se encuentra base en las cédulas reales para avalar esta opinión.

Lo dicho de la agricultura vale también para la ganadería. Caso muy distinto es el cultivo de la coca, hierba sumamente apreciada e incluso supersticiosamente venerada por los indios; pero sabemos por experiencia los graves perjuicios que les ocasiona con ganancias abusivas para los españoles que la trafican ${ }^{160}$. Por eso las cédulas reales lo prohíben. Ya el Concilio II Límense de 1567 había dado la voz de alarma: «Que la coca es cosa sin provecho y muy aparejada para el abuso y superstición de los indios; y de comerla, los indios tienen poco fruto, y de beneficiarla mucho trabajo; y que por su ocasión han perecido y perecen muchos. Y así se desea que los gobernadores quiten a los indios el trabajo de beneficiar la coca, o al menos no los fuercen contra su voluntad» ${ }^{161}$.

Si se controlan y corrigen los posibles abusos de los particulares, también parece cumplir las condiciones de justicia la industria telar como los obrajes de paños muy buenos de todo tipo, bayetas, mantas y otros tejidos «de igual estima, que casi se pueden comparar con los mejores que se llevan de España» ${ }^{162}$. El trabajo no les es muy gravoso y pueden realizarlo «dentro de sus temples y cerca de sus pueblos y casas», se ganan con él unos buenos salarios (incluso muchachos de nueve o diez años), obtienen a precio moderado paños para bien vestirse y mejorar su nivel de vida ${ }^{163}$.

156 Juan SolórzAno, Política indiana, lib. II, cap. 7, n. 68 (BAE 252, 196).

157 Juan SolórZAno, Política indiana, lib. II, cap. 8, nn. 1-2 (BAE 252, 199-200).

158 Juan SolóRZAno, Política indiana, lib. II, cap. 9, n. 1 (BAE 252, 203-204).

159 Juan Solórzano, Política indiana, lib. II, cap. 9, n. 3 (BAE 252, 204).

160 Juan Solórzano, Política indiana, lib. II, cap. 10, nn. 1, 7 (BAE 252, 213-214).

161 Segundo Concilio Límense 1567 cap. 124 (ed. F. Mateos, Madrid, 1950, p. 87). Juan SolórZANO, Política indiana lib. II, cap. 10, n. 12 (BAE 252, 216).

162 O. c., lib. II, cap. 12, n. 1 (BAE 252, 229-230).

163 O. c., lib. II, cap. 12, nn. 7-9 (BAE 252, 231).

Hispania Sacra, Missionalia hispanica, 58

117, enero-junio 2006, 263-327, ISSN: 0018-215-X 
También parece estar justificado el servicio de los tambos (mesones) y tamemes (transporte de cargas), si se guardan las debidas condiciones. Este servicio, que también tiene lugar en España, es necesario para el fomento del comercio. Especialmente delicado, en lo tocante a justicia, es el servicio de tamemes, por los abusos a que fácilmente está expuesto y que encontraron siempre su corrección en las leyes. Las Nuevas Leyes mandaban ya tener especial cuidado «que no se carguen [los indios] o en caso que esto en algunas partes no se pueda expresar, sea de tal manera, que de la carga inmoderada no se siga peligro en la vida, salud y conservación de los dichos indios, y que contra la voluntad de ellos y sin se lo pagar, en ningún caso se permita que se pueda cargar, castigando muy gravemente al que lo contrario hiciere. $Y$ en esto no ha de haber remisión por respecto de persona alguna» ${ }^{164}$. De todas maneras, si se toman las debidas precauciones, cree Solórzano que no es injusto ni pernicioso cargar a los indios, costumbre que estuvo siempre vigente entre ellos y que también en España practican los mozos de cuerda ${ }^{165}$.

También José de Acosta está de acuerdo con este parecer entendido con las limitaciones reseñadas de moderación y justicia. Y así concluye: «Por tanto, si la carga es moderada, el trayecto no más largo de lo debido y el precio no es menos de lo justo, no hay de suyo nada de malo en ello... Por consiguiente, como los indios son gente muy acostumbrada a llevar cargas entre nosotros, si no se les apura más de lo justo, no se les causa ninguna injusticia ni excesivas molestias. Siempre bajo la condición, como he dicho, de que se guarden los límites establecidos en cuanto al peso, trabajo y precio» ${ }^{166}$.

Tomás López Medel, encargado precisamente de ejecutar las Nuevas Leyes en la Audiencia de Guatemala, sostiene la misma opinión y lamenta en la carta que dirigió a los Reyes de Bohemia en 1551 los inconvenientes que acarreó quitarse «los tamemes de repente, sin abrir los caminos y proveer arrias... Por lo cual forzados, hobimos de disimular con los tamemes. No hay arrias en esta tierra, y si algunas, tan pocas que no se hace caso de ellas... Ello... no es contra la ley de Dios, antes es conforme a ella, pues le manda al hombre que del sudor de su vulto busque su comida. Éstos [los indios] — prosigue Medel— no tienen otra granjería ni otra habilidad ni otro oficio, sino éste. Quitarles la ocasión de ganar un real es recia cosa... Lo que por agora se debería guardar con todo cuidado... que de tierra fría no salgan a caliente ni por el contrario, y que la carga sea moderada y se les pague a ellos propios» ${ }^{167}$.

Otro de los servicios de utilidad pública que viene exigido por el bien co-

\footnotetext{
164 O. c., lib. II, cap. 13, n. 15 (BAE 252, 243).

165 O. c., lib. II, cap. 13, nn. 11 y 13 (BAE 252, 242-243).

166 José DE ACOSTA, De procuranda indorum salute lib. III, cap. 17, nn. 10 y 11 (CHP 23, 525).

167 Tomás López Medel, Carta a los Reyes de Bohemia, Guatemala a 25 de marzo de 1551 (CHP 28, 63-64).
} 
mún es el de correos. Esta misma nota de necesidad lo justifica ya suficientemente, con tal de que se trate y se pague bien a los indios que realizan el trabajo, como sostienen también Juan de Matienzo y José de Acosta. Hay cédulas que asignan también este servicio a los españoles para alivio de los indios. Por parte de las autoridades se procura además por todos los medios salvaguardar la libertad y seguridad en el escribir, esenciales para la justicia y eficacia del servicio $^{168}$.

Felipe II en carta de 1592 al Marqués de Cañete, Virrey del Perú, le recuerda que correos «es el instrumento con que las gentes se comunican; y demás de ser ofensa de Nuestro Señor abrir las cartas, éstas han sido y deben ser inviolables a todas las gentes, pues no puede haber comercio ni comunicación entre ellos por otro camino, ni le hay para que yo sea informado del estado de las cosas en esas partes ni para que los agraviados que no pueden venir con sus quexas me den cuenta de ellas... y conviene lo mucho que se dexa entender no dar lugar ni permitir cosa semejante; pues demás de lo sobredicho, es opresión y violencia e inurbanidad, que no se permite entre gentes que viven en cristiana policía» ${ }^{169}$.

El servicio que suscitó más polémica y opiniones más encontradas fue el de minas. Dadas sus muy peculiares características, ¿se dan de hecho en este servicio las condiciones de justicia exigidas por los servicios de necesidad pública? ¿Se puede lícitamente obligar a los indios al trabajo de minas? Juan de Matienzo, José de Acosta, Jerónimo de Loaysa y otros están por la respuesta afirmativa: los metales que se extraen de las minas son necesarios para la conservación de las dos repúblicas que, ya mezcladas, constituyen españoles e indios; son el fundamento económico que sustenta todo el edificio administrativo tanto civil como eclesiástico.

Por otra parte, como dice Acosta, todo este problema ha sido ya concienzudamente estudiado en una consulta de teólogos y juristas (se refiere probablemente a la Junta de México de 1547). «Y ahí están las leyes y ordenanzas que determinan el orden y moderación en la extracción de metales, para que se mire bien por la salud y comodidad de los indios. No creo, pues, que me corresponda a mí reprobar el parecer de tan insignes varones y mucho menos reclamar leyes nuevas con que se mitigue la situación tan dura de los indios» ${ }^{170}$. Acosta dejó señaladas las condiciones sin las cuales no podría justificarse el trabajo en minas; atención espiritual y corporal en el trabajo, moderación en el mismo, clima natal, salario justo, alimentación sana, cuidado de los enfermos y turnos rotativos de trabajo. «Si los nuestros observan, como es razón, estas condiciones de

\footnotetext{
168 Juan SolóRZAno, Política indiana, lib. II, cap. 14, nn. 1-2, 12, 22 (BAE 252, 251-252, 254,

169 O. c., lib. II, cap. 14, n. 28 (BAE 252, 257).

170 José DE Acosta, De procuranda indorum salute, lib. III, cap. 18, n. 4 (CHP 23, 535).
} 255). 
la ley, tal como han sido ideadas por varones doctos, nos parece que hay que ser tolerantes con ellos, no sea que, acabándose el comercio, se desplome también el trabajo de la predicación evangélica. Pero si no cumplen estas premisas y tratan cruelmente a los indios como si fueran esclavos, vean ellos la cuenta que habrán de dar a Dios, que es padre de los pobres y juez de los huérfanos» ${ }^{171}$.

Sin embargo, no para todos quedó definitivamente ventilada esta materia con las razones expuestas, que a Solórzano le parecen sólidas y de peso. Algunos, en efecto, pensaban que los indios son de floja complexión y no pueden ser obligados a tan intolerables servicios ni a exponer su vida para que otros se enriquezcan. Y esto aunque el trabajo se haga por turnos y los indios estén bien pagados $^{172}$.

Por lo demás, las minas ofrecen muchas más ocasiones de maltratar a los indios que las que podían tener sus encomenderos, como demuestra la experiencia $^{173}$. Y sólo una pequeña parte de los abusos pueden llegar a noticia de la justicia, por las condiciones y la soledad en que se desarrolla el trabajo ${ }^{174}$.

Finalmente, este servicio es más penoso que el de los tamemes, porque los indios deben cargar con sus herramientas, la comida y los metales; «y esto no por caminos abiertos, seguidos y de aire puro y adonde pueden parar cuando se sintieren cansados, como sucede en las cargas de los trajines, sino por vueltas y revueltas obscuras, lóbregas y de corta o malsana respiración, cuales de ordinario, al modo del Laberinto de Dédalo, suelen ser las minas, y trepando por escalas dificultosas y mal seguras ${ }^{175}$. En cualquier caso, mejor se conservarán estas dos repúblicas, «que hoy se hallan unidas y mezcladas de españoles e indios y deben mutuamente ayudarse en lo que pudieren» ${ }^{176}$, si se libera a los indios de este inhumano trabajo, puesto que con él se acaban los vasallos; y nunca con la explotación se puede engrandecer u reino ${ }^{177}$.

Estas razones en materia tan dificultosa le obligan a Solórzano a tomar una vía media en la solución del problema: Como ya dijera José Acosta, no es de parecer que dejen de buscarse y explotarse las minas en tiempo de tan urgentes necesidades, sino que «se laboren por medios y modos tan lícitos y suaves, que en ellos mismos podamos fundar y asegurar la abundancia que se procura y la que a los que son tales tiene prometida el Espíritu Santo en los Proverbios» ${ }^{178}$. Y unos de estos medios sería el de explotarlas por esclavos que «deben ser bien

171 O. c., lib. III, cap. 18, n. 5 (CHP 23, 537).

172 Juan Solórzano, Política indiana, lib. II, cap. 16, nn. 1-3, 7-8 (BAE 252, 274, 275).

173 O. c., lib. II, cap. 16, n. 36 (BAE 252, 280).

174 O. c., lib. II, cap. 16, n. 39 (BAE 252, 280).

175 O. c., lib. II, cap. 16, n. 45 (BAE 252, 281).

176 O. c., lib. II, cap. 16, nn. 55-56 (BAE 252, 283).

177 O. c., lib. II, cap. 16, nn. 58 y 64).

178 O. c., lib. II, cap. 17, n. 21 (BAE 252, 292-293). 
tratados, sin castigarlos ásperamente ni exponerlos a riesgos y peligros notorios de vida» ${ }^{179}$. Pero bien podríamos replicar que esta medida pensada por Solórzano no lograría sino trasladar el problema a otra zona, pero no resolverlo..

«También sería más lícito y tolerable, si se ejercitare por indios que voluntariamente quieran conducirse para él, o por españoles o por negros libres, mestizos o mulatos, de que hay tanta muchedumbre en las Indias; y pagándoles bien, no dexarán algunos de aplicarse a este trabajo, como lo hacen en Alemania y en otra provincias y se experimenta en los indios que de su voluntad se alquilan o mingan en Potosí, en Huancavelica y en las minas de San Luis, Zacatecas y Pachuca de la Nueva España» ${ }^{180}$. Y aunque el trabajo, por su gran dureza, nunca será suficientemente bien compensado, sin embargo, «el ser voluntario quita la nota de opresión y de injuria, según lo enseña el Derecho» ${ }^{181}$.

Se han de levantar poblaciones en los mismos asientos de las minas, evitando sacarlos de sus temples. "Y no sería menos conveniente condenar a este trabajo hombres facinerosos y delincuentes, ya sean españoles ya indios ya negros libres o esclavos, mestizos o mulatos, mandan a los jueces que en lugar de otras penas impongan esta, cuando la gravedad de sus delitos lo mereciere» ${ }^{182}$. Esto, a su vez, serviría de freno, para que no se cometiesen tantos delitos en las Indias, «con reformación general de costumbres; y los que los cometiesen pagarían allí su pecado teniendo por clemente esta pena, si la merecieron de muerte» 183 .

Pero el medio principal para que la necesaria explotación de las minas no llegue a paralizarse por acabamiento de los indios es que todos, «aunque sean los españoles más estirados, se apliquen a trabajar en ellas y a poner, como dicen, el hombro a la carga y la mano al arado, sin esperarlo todo del trabajo y sudor de los indios» ${ }^{184}$. En todo caso, mejor es vivir con más parsimonia que acumular riquezas y lujo a costa de la salud de los indios ${ }^{185}$.

\section{Educación y promoción de los indios}

La tarea más importante y de más alta responsabilidad que incumbe a todo gobernante es si duda la de educar y promocionar a sus súbditos. La sociabilidad del ser humano exige que los miembros de una comunidad política alcan-

\footnotetext{
179 O. c., lib. II, cap. 17, n. 23 (BAE 252, 293).

180 O. c., lib. II, cap. 17, n. 25 (BAE 252, 293).

181 O. c., lib. II, cap. 17, n. 27 (BAE 252, 294).

182 O. c., lib. II, cap. 17, nn. 29-30 (BAE 252, 294).

183 O. c., lib. II, cap. 17, n. 32 (BAE 252, 294).

184 O. c., lib. II, cap. 17, n. 44 (BAE 252, 296).

185 O. c., lib. II, cap. 17, nn, 45-48).
}

Hispania Sacra, Missionalia hispanica, 58 
cen un grado mínimo de civilización sin el cual se haría imposible o muy difícil una verdadera convivencia. No sería posible una sociedad justa y bien ordenada, si sus miembros estuvieran sumidos en la barbarie. Y cometería gravísima injusticia el soberano que descuidase este deber esencial e irrenunciable de gobierno. Es, por tanto, obligado preguntarse cuál fue la actitud y la actuación concreta de la Corona española en una cuestión de tanta importancia para decidir sobre la justicia o injusticia de su gobernación y administración en Indias. Es un tema que no podía escapar a la revisión crítica de Solórzano.

Quizás la manifestación más llamativa e importante, por su radicalidad y originalidad, de la obra civilizadora de España en Indias, la constituían las llamadas Reducciones, que se procuraron llevar a cabo desde los primeros momentos. Había que reducir, juntar en pueblos civilizados a los indios que malvivían, como bestias, esparcidos por montes y campos, en chozas o en cuevas, sin leyes ni reyes ni forma de vivir que se diferenciase mucho de la de los brutos ni mereciese llamarse digna de un ser humano ${ }^{186}$; «y en muchas partes vivían como bestias en los campos, sin rastro ni conocimiento bastante de vida sociable y política ${ }^{187}$. Tarea que estimaba imprescindible para su evangelización y promoción humana.

Solórzano constata el interés que siempre acompañó a nuestros reyes por reducir a los indios a formas de vida civilizada acordes con la dignidad humana. Y lo creían tan importante para redimirlos de su estado de postración, que ordenaron que «aunque no quisiesen, se les señalasen puestos y sitios acomodados donde labrasen pueblos y casas a sus modos y comenzasen a vivir como hombres, deponiendo sus antiguas y fieras costumbres y haciéndose con esto más hábiles para recibir nuestra santa fe y religión cristiana, que es lo que sobre todo se ha procurado y en la cual en otra suerte jamás se pudieran hacer progresos considerables» ${ }^{188}$.

Acosta vio con claridad la necesidad de las reducciones para enseñar a los indios a ser hombres y cristianos. «El primer cuidado del gobernante - dicedebe ser atraer a estos hombres salvajes y fieros a géneros de vida humana y amoldarlos a formas civilizadas. En vano enseñaremos las cosas divinas y celestiales a quien vemos que ni siquiera es capaz de entender y procurar las humanas» ${ }^{189}$. Y aunque los mayores se resistan al cambio por aferrarse a sus costumbres pasadas, «hay que buscar la enmienda en los pequeños, es decir, en los niños y jóvenes con una esmerada educación... Los cimientos que pongas en la juventud condicionarán el edificio para el resto de sus vidas» ${ }^{190}$. Porque ocu-

186 O. c., lib. II, cap. 24, n. 4 (BAE 252, 372).

187 O. c., lib. II, cap. 24, n. 11 (BAE 252, 374).

188 O. c., lib. II, cap. 24, n. 11 (BAE 252, 374).

189 José DE AcOSTA, De procuranda indorum salute, lib. III, cap. 19, n. 1 (CHP 23, 539).

190 O. c., lib. III, cap. 19, n. 3 (CHP 23, 541-243). 
rre, añade Solórzano, que «algunos hombres, por falta entera de capacidad, no saben estimar ni abrazar lo que se les propone para bien suyo»; y entonces es lícito al gobernante hacerles entrar por el buen camino, aunque se resistan ${ }^{191}$.

Y esto es, opina Solórzano, lo que con toda justicia y celo han procurado siempre nuestros reyes obligando a los indios a reducirse o juntarse en pueblos al estilo de los españoles. Esta fue también una de las ideas clave del gran Visitador y Oidor de Guatemala, Tomás López Medel, en su programa de reformas sociales y urgentes. Cree necesario que los indios «sean compelidos a juntarse sus poblaciones y avecindarse juntos, que no estén en lugares endeviados ni apartados, por que haya lugar de doctrinarlos y conversarlos, que es necesario para su policía y conversión. Y hanse de poblar en tales lugares, que sean oportunos para sus labranzas y salud... y en tal disposición, que a caballo e a pie, como quisieren, puedan entrar en ellos, Háseles de mandar que sus pueblos los tracen por sus barrios y calles al modo de España, y que dende luego señalen sus edificios públicos» ${ }^{192}$. Y va dejando en sus visitas instrucciones muy concretas sobre cómo se deben erigir, establecer y gobernar las nuevas poblaciones de indios reducidos.

Todas las personas de consejo o con responsabilidad de gobierno, tanto civiles como eclesiásticas, con raras excepciones, estaban de acuerdo en que la reducciones eran punto de partida y condición indispensable para hacer posible la instrucción y formación cristiana de los indios. Este era precisamente el fin principal y constituía además una prueba incontestable de la justicia con que la Corona gobernaba las Indias.

Solórzano recuerda que el Concilio II Provincial de Lima (1567) encarga que «se enseñe a los indios a vivir con orden y policía, tener limpieza y honestidad y buena crianza y que, como acostumbran los cristianos, digan la bendición a la mesa y den gracias después de comer, y cuando van a dormir se encomienden a Dios» ${ }^{193}$. Y el Concilio III Provincial de Lima (1583), en el que José de Acosta tuvo una destacadísima actuación, reproduce casi literalmente expresiones que Acosta había dejado ya formuladas en su obra De procuranda indorum salute: «Que mal pueden ser enseñados a ser cristianos, si primero no les enseñamos a que sepan ser hombre y vivir como tales, que se hagan a las costumbres de hombres políticos, como son entrar aseados y limpios en las iglesias..., tener mesas para comer y lechos para dormir en alto y no en el suelo, como lo hacían, y las casas con tanta limpieza y aliño, que parezcan habitaciones de hombres y no chozas o pocilgas de animales inmundos, y otras cosas que se les

\footnotetext{
191 Juan SolóRZAno, Política indiana lib. II, cap. 24, n. 27 (BAE 252, 377).

192 Tomás López MEDEL, Informes y testimonios (CHP 28, 92-93).

193 Rubén Vargas Ugarte, Concilio Limenses (1551-1772). Segundo Concilio Provincial Limense 1567, II Parte, cap. 112 (Lima, 1951, p. 253).
}

Hispania Sacra, Missionalia hispanica, 58

117, enero-junio 2006, 263-327, ISSN: 0018-215-X 
irá persuadiendo no tanto con imperio violento y severo como con amor, cuidado y gravedad paternal» ${ }^{194}$.

Para lograr estos objetivos es preciso partir de un principio pedagógico que ya había señalado Acosta: la labor educativa es lenta, exige ir paso a paso con mucha paciencia; no hay que intentar «pasarlos luego de un extremo a otro ni ajustarlos del todo a lo riguroso de nuestras leyes» ${ }^{195}$. Acosta decía que no hay que alarmarse porque todavía se mantengan en los pueblos bautizados «muchos resabios de su antigua barbarie, superstición y modo de vida animal, sobre todo si se tiene en cuenta que son de ruda condición y que nuestra diligencia no es comparable en modo alguno con el esfuerzo de los antiguos. Poco a poco las costumbres se van cambiando a mejor» ${ }^{196}$. Hay que respetar y tolerar aquellas costumbres bárbaras que no se opongan claramente a la ley natural y evangélica.

Este principio lo intuyó con su habitual penetración Tomás López Medel y lo convirtió en norma de gobierno, mientras ejerció los cargos de Visitador y Oidor. En su informe de 1551 afirmaba que «no todo se ha de hacer de una vez. Cosas hay que es mejor dexarlas para que el tiempo las reforme. Y las que tuvieren necesidad de reformación, que se haga poco a poco y con tiento, y no de golpe, por que haya lugar de arrepentirnos y mudar el consejo, si pareciere que conviene» 197 .

Y ese es también, a juicio de Solórzano, el principio que guió e inspiró la legislación de la Corona española. Felipe II en la cédula real de 1555 permite que los indios sigan usando de sus antiguas buenas leyes y costumbres; pero hay que desarraigar las que son torpes, como los incestos, la sodomía, la de comer carne humana, las idolatrías, los sacrificios humanos o de animales a los ídolos ${ }^{198}$.

Tarea de educación es también habituarlos a trabajar, «porque siempre han sido notados de flojos y lo reconoce el Padre Acosta, con ser en lo demás su gran defensor, para que se destierren los daños y vicios que en todo género de gentes causa la flojedad y ociosidad, y ganen lo necesario para su sustento» ${ }^{199}$.

Admite, en efecto, Acosta que los bárbaros son en general indolentes y perezosos para el trabajo y reconoce «que trabajar, negociar y estar ocupados en sus granjerías y tratos es ciertamente muy provechoso a los bárbaros y es

194 Juan SolóRzano, Política indiana, lib. II, cap. 25, n. 4 (BAE 252, 384). Cfr. Rubén VARGaS Ugarte, Concilios Limenses (1551-1772). Decretos de la quinta acción del Concilio Provincial de Lima que se publicaron en la Iglesia Catedral en diez y ocho días del mes de octubre del año de mil y quinientos y ochenta y tres años. Capítulo 4 (Lima, 1951, t. I, pp. 373-374).

195 Juan Solórzano, Política indiana, lib. II, cap. 15, n. 8 (BAE 252, 385).

196 José DE ACOsTA, De procuranda indorum salute, lib. I, cap. 8, n. 2 (CHP 23, 155-157).

197 Tomás LóPEz Medel, Colonización de América. Informes y testimonios (CHP 28, 73-74).

198 Juan SolóRZAno, Política indiana, lib. II, cap. 25, nn. 12 y 22-25 (BAE 252, 386 y 388-389).

199 O. c., lib. II, cap. 25, n. 26 (BAE 252, 389). 
completamente necesario para organizar, de la forma que sea, su república ${ }^{200}$. Y está convencido de que «el objetivo más importante ha de ser cortar con la mayor diligencia la indolencia y ociosidad de los pueblos indios. Son vicios a los que están dados por naturaleza, que les embotan todo sentimiento de vida humana y los aprisionan no poco en el vicio de la impureza» ${ }^{201}$. Por eso las cédulas mandan que se les haga trabajar, para que ganen su sustento y colaboren al bien común.

Se manda así mismo que «no anden desnudos, sino que los caciques y principales anden todos vestidos y sus mujeres; los demás hombres y mujeres siquiera de la cintura abaxo y cubiertas sus vergüenzas; precepto que fue muy conveniente, porque en muchas partes usaban andar los más desnudos del todo» ${ }^{202}$.

Otro de los vicios que se ha de desarraigar en los indios es el de las borracheras (sobre todo el de la borracheras públicas y sacrílegas), por perjudicarles en tanto grado, «que dicen muchos que son más los que han muerto por el vino, chicha y pulque y otras bebidas que componen de varias raíces, con las cuales tienen por deleite emborracharse, que con cuantas pestes, calamidades y trabajos les han sucedido», como advierte el Padre José de Acosta ${ }^{203}$.

Pero más execrable es que sean los españoles mismos, especialmente corregidores y doctrineros, quienes se enriquezcan haciendo su gran negocios con toda clase de bebidas. No sólo las permiten, sino que obligan a los indios a comprarlas y beberlas vendiéndoselas a precios elevados. Por eso bien concluye Acosta: «Eso es lo que hacen nuestros españoles y tales ganancias obtienen de la perdición de las almas incluso los que son más apuestos y religiosos. ¿Qué esperanza puede quedar de la salvación de estos infelices, cuando les proporcionan el veneno los mismos de quienes se debía esperar el remedio?» ${ }^{204}$. La denuncia busca una vez más la promoción de la justicia en la convivencia de la sociedad indiana.

Finalmente, el plan de rehabilitación del indio exigía (y así se hizo) extirpar la inicua y cruel costumbre de enterrar o quemar «con los caciques y nobles de ellos que morían, a sus mujeres y criados vivos, como para que les fuesen a acompañar y servir a la otra vida» ${ }^{205}$.

Un punto controvertido que pareció de importancia capital para emprender con eficacia la humanización y cristianización de los indios era el apren-

\footnotetext{
200 José DE Acosta, De procuranda indorum saluate, lib. III, cap. 9, n. 1 (CHP 23, 443).

201 O. c., lib. III, cap. 19, n. 3 (CHP 23, 543).

202 Juan SolóRZAno, Política indiana, lib. II, cap. 25, n. 27 (BAE 252, 390).

203 O. c., lib. II, cap. 25, n. 30 (BAE 252, 390).

204 José DE Acosta, De procuranda indorum salute, lib. III, cap. 22, n. 6 (CHP 23, 577); Juan SoLÓRZANO, Política indiana, lib. II, cap. 25, n. 39 (BAE 252, 392).

205 O. c., lib. II, cap. 25, n. 40 (BAE 252, 393).

Hispania Sacra, Missionalia hispanica, 58

117, enero-junio 2006, 263-327, ISSN: 0018-215-X
} 
dizaje de la lengua castellana. ¿Era o no justo imponer el castellano como lengua común en las Indias? Razones de diversos tipo parecían aconsejarlo. La enorme multiplicidad de lenguas existentes en las Indias (Acosta habla de más de setecientas) ocasionaba muchas y casi insuperables dificultades para la conversión de los indios y para una amistad y comunicación con ellos, «porque todos somos sordos en las lenguas que no entendemos... Y lo mismo es no hablar que hablar de suerte que no nos entendamos» ${ }^{206}$. También José de Acosta se expresa asombrado sobre esta multiplicidad de lenguas indígenas, cuando dice: Esta y no otra es la razón por la que se ha puesto en cuestión la conveniencia de obligar a los indios «a que forzosamente aprendan y hablen nuestra lengua, de tal suerte que olviden y dexen del todo las suyas; o por el contrario, nos acomodemos nosotros a aprender esas para poderles explicar el evangelio y catequizarlos, comerciar y negociar en lo demás que se ofrezca» $^{207}$.

El Concilio III Provincial de Lima, algunas cédulas e instrucciones antiguas y autores que han estudiado de cerca la cuestión, como Acosta y Gracilazo, opinan que a los indios no se les puede quitar su lengua y que somos nosotros los que debemos aprender la suya. He aquí el argumento de Acosta: «Si unos pocos españoles, estando en patria extraña, no pueden con todo olvidar su propia lengua y aprender la extranjera, siendo de excelente ingenio y viéndose constreñidos por la necesidad de entenderse, ¿en qué cabeza cabe que innumerables gentes tengan que olvidar la lengua de sus padres en su propia patria y usar sólo de un idioma extranjero que oyen raras veces y muy a disgusto? Y cuando dentro de sus casas además tratan de sus asuntos en su lengua materna, ¿quién los sorprenderá? ¿Quién los denunciará? ¿Cómo les obligará a hablar español?» ${ }^{208}$. Y por otra parte, difícilmente se podrá conseguir que tantos abandonen la propia lengua y se apliquen con gusto a aprender la ajena; «pues aun sólo el oírla les suele ser muy odioso» ${ }^{209}$.

A pesar de estas razones, «yo siempre — nos dice Solórzano de sí mismome he inclinado más a la opinión contraria», por los inconvenientes indicados de la multiplicidad de lenguas. Lo más conveniente hubiera sido obligar a todos los indios desde el principio a aprender el castellano, de manera que los viejos «no dexaran de aprender lo que bastara para entendernos; y en los muchachos y en los que después fuesen naciendo no podía haber alguna, pues toman y aprenden con tanta facilidad cuantas les quisieren enseñar» 210 . Hasta el punto que olvidaran la propia, de suerte que «ya no supiéramos cuál había sido», como nos

206 O. c., lib. II, cap. 26 nn. 3-4 (BAE 252, 396).

207 O. c., lib. II, cap. 26, n. 6 (BAE 252, 396-397).

208 José DE AcostA, De procuranda indorum salute, lib. VI, cap. 8, n. 1 (CHP 24, 63).

209 Juan SolórZAno, Política indiana, lib. II, cap. 26, n.10 (BAE 252, 397).

210 O. c., lib. II, cap. 26, n. 12 (BAE 252, 398). 
ocurrió a los españoles con el latín ${ }^{211}$. Y de esta opinión es también Juan de Matienzo.

En segundo lugar, la enseñanza del castellano es sumamente necesaria (y en este sentido se expresan muchas cédulas reales), «para que los nuestros se estrechen más con los indios y ellos con nosotros y puedan ser instruidos en nuestra santa fe católica y mandar que desde niños sean aplicados a ella y tengan escuelas para este efecto en los conventos dominicanos, agustinianos y otros» ${ }^{212}$.

A este respecto, en la cédula real de 7 de junio de 1550 se ordena la introducción de la lengua castellana para la predicación del Evangelio en los siguientes términos: «Habiendo hecho particular examen sobre si aun en la más perfecta lengua de los indios se pueden explicar bien y con propiedad los misterios de nuestra santa fe católica, se ha reconocido que nos es posible sin cometer grandes disonancias e imperfecciones. Y aunque están fundadas cátedras donde sean enseñados los sacerdotes que hubieren de doctrinar a los indios, no es remedio bastante por ser mucha la variedad de lenguas. Y habiendo resuelto que convendría introducir la castellana, ordenamos que a los indios se les pongan maestros que enseñen a los que voluntariamente la quisieren aprender como les sea de menos molestia y sin costa. Y ha parecido que esto podrían hacer bien los sacristanes, como en las aldeas de estos reinos enseñan a leer y escribir y la doctrina cristiana» ${ }^{213}$.

Y está también, como acaba de indicarse, la razón del mutuo conocimiento, aprecio y amor; «cosa que en sumo grado se consigue con la inteligencia y conformidad del idioma». Porque, como dice el Padre Blas Valera, «la semejanza y conformidad de las palabras cuasi siempre suelen reconciliar y traer a verdadera unión y amistad a los hombres» ${ }^{214}$. Y es lo que hicieron los incas y Moctezuma introduciendo en sus imperios la lengua general quechua y mexicana ${ }^{215}$.

Además de la enseñanza de la lengua, ayudaría también a la educación de los indios obligarles a que «en el traje y modo de vestir y en las demás costumbres loables, que no repugnasen mucho al estado o condición, se ajustasen a las de los españoles y a su trato, comercio y comunicación» ${ }^{216}$. Es decir, había que españolizarnos lo más posible. No es este, en cambio, un criterio que tenga cabida en el sistema pedagógico de Acosta. Entre las reglas que junto con el entonces Visitador de la Compañía de Jesús en el Perú, padre Juan de la Plaza, redactó para el colegio de los hijos de caciques, se encuentra el siguiente aviso

211 O. c., lib. II, cap. 26, nn. 13-14 (BAE 252, 398).

212 O. c., lib. II, cap. 26, n. 20 (BAE 252, 399).

213 Recopilación, lib. VI, tít. 1, ley 18. f. 190 (Colección de Documentos Inéditos para la Historia de España I, 272-273).

214 Juan SolóRZANo, Política indiana, lib. II, cap 26, nn. 30-31 (BAE 252, 400).

215 O. c., lib. II, cap. 26, n. 37 (BAE 252, 402).

216 O. c., lib. II, cap. 26, n. 40 (BAE 252, 403).

Hispania Sacra, Missionalia hispanica, 58

117, enero-junio 2006, 263-327, ISSN: 0018-215-X 
para el director del colegio: «Las leyes y costumbres y modo de gobernar que ellos tienen en sus tierras, que no es contrario a la ley cristiana y natural, no es bien quitársele; ni conviene hacerles españoles en todo, porque demás de ser muy difícil, es gran perjuicio para su gobierno y república de ellos» ${ }^{217}$.

Con miras así mismo a la educación y regeneración del indio se han promovido los matrimonios mixtos de españoles con indias o indios con españolas. Y recuerda Solórzano que, aunque antiguamente parece haber estado prohibidos, ya las cédulas de 1514 y 1515 los permitieron, «porque pareció, se tuvo y se tiene por conveniente para la entera libertad que el derecho requiere en los matrimonios y para la población de estas provincias, su aumento, conservación y buena correspondencia que se desea entre indios y españoles» ${ }^{218}$.

Estamos, evidentemente, en los antípodas del racismo; se erige incluso en principio pedagógico del sistema educacional la igualdad y la integración, bajo todos los aspectos, de españoles e indios en una única comunidad política desde la misma célula elemental de la familia. Está puesta la base para una nueva sociedad gobernada en justicia.

El papel preponderante que todavía desempeñaban entre los indios los curacas o caciques no podía quedar silenciado en el plan general de educación. La importancia de estos señores naturales y la influencia que ejercían sobre los indios, sus súbditos, era tan avasalladora, que «no se atreven a replicar ni aun abrir la boca a cuanto les mandan, por duro y trabajoso que sea, y quieren más morir y perecer que desagradarles. De donde ha nacido que, usando mal de esta sumisión y rendimiento natural que conocen en ellos, no hay cosa grave que les manden ni de precio que no se la quiten, haciéndoles en las cobranzas de los tributos y en los repartimientos de las mitas y en todo lo demás que pueden infinitas estafas y extorsiones y violencias» ${ }^{219}$.

Por eso, objeto de capital importancia para la conversión y educación de los indios ha de ser ganar a los curacas, «de cuya voluntad — decía el Concilio II Provincia del Lima - penden los demás sin resistencia ninguna, siendo cosa cierta del todo que la fe y salvación de los indios pende de la voluntad y autoridad de los caciques» ${ }^{220}$. Y así lo dejó también advertido Acosta: «Ciertamente hay que tratar de ganarse con suavidad y diligencia la voluntad de los curacas y caciques y conquistarles para Cristo» ${ }^{221}$. De ahí la enorme importancia de que se funden colegios para educar a los hijos de los caciques, donde «desde sus tiernos años sean instruidos con mucha enseñanza y fundamento en nuestra

217 Monumenta Historica S. J., Monumenta Peruana, II, cap. 460, n. 5.

218 Juan SolórZAno, Política indiana, lib. II, cap. 26, n. 44 (BAE 252, 403-404)

219 O. c., lib. II, cap 27, n. 6 (BAE 252, 407).

220 O. c., lib. II, cap. 27, n. 36 /BAE 252, 413).

221 José DE AcosTA, De procuranda indorum salute, lilb. II, cap. 18, n. 2 (CHP 23, 375). 
santa fe católica y en costumbres políticas y en la lengua española y comunicación de los españoles, para que así salgan y sean, cuando grandes, mejores cristianos, más entendidos y nos cobren más afición y voluntad y puedan enseñar, persuadir y ordenar después a sus sujetos todo esto con mejor disposición y mayor suficiencia» ${ }^{222}$.

Una idea largamente acariciada por Acosta fue la de fundar escuelas y colegios para la educación de los niños, sobre todo colegios para hijos de caciques. Siendo Superior Provincial del Perú (1576-1582) dejó trazado, en colaboración con el entonces Visitador de los jesuitas Padre Plaza, un ideario para la recta dirección de estos colegios, uno de cuyos puntos rezaba así: «Sean instruidos en el oficio que han de hacer con sus indios, para que lo hagan bien y cristianamente» ${ }^{223}$. Se les manda también que hablen ordinariamente español. Era la aplicación práctica del principio pedagógico que había dejado formulado en su obra De procuranda indorum salute: «Los cimientos que pongas en la juventud condicionarán el edificio para el resto de la vida ${ }^{224}$.

También Tomás López Medel había insistido machaconamente, en su informes a la Corona, en la necesidad de levantar escuelas en todos los pueblos, a las que acudiesen obligatoriamente todos los niños. Incluso se atreve a proponer al rey que se encomiende este cuidado a los jesuitas. He aquí sus palabras: «Y porque de la Compañía de Jesús se opera allá mucho fruto, provéase dinero o un representante para fundar allá un colegio con los ministerios siguientes: primero, funden y sustenten muchos seminarios de niños en pueblos de indios y españoles. Segundo, dos o tres cátedras de latinidad, moral y otras profesiones para hijos de vecinos y los demás, que sin esta ocupación sin remedio serán muy viciosos, y los que quisiesen ordenarse tendrán donde aprender las letras necesarias para ello...» 225 .

Es este un deseo que el propio Solórzano hace también suyo, «por ser — dice refiriéndose a la Compañía de Jesús - un Instituto acomodado para executarle según se requiere y en todas partes nos lo ha mostrado la experiencia» ${ }^{226}$. Y refiere seguidamente una deesas experiencia por él mismo vivida: «Por lo cual yo, cuando estuve en Lima, habiéndose exigido allí un colegio para estos hijos de caciques y otros en la ciudad del Cuzco, fui de parecer que se les encargase. Así se hizo y se va continuando, según entiendo, con buenos resultados» $\gg^{227}$.

\footnotetext{
222 Juan SolóRZANo, Política indiana, lib. II, cap. 27, n. 39 (BAE 252, 414).

223 Monumenta Historica S. J., Monumenta Peruana, II, n. 1, p. 458.

224 José DE Acosta, De procuranda indorum salute, lib. III, cap. 19, n. 3 (CHP 23, 543).

225 Tomás LóPEZ Medel, Informes y testimonios (CHP 28, 295-296).

226 Juan SolóRzAno, Política indiana, lib. II, cap, 27, n. 43 (BAE 252, 414).

227 O. c., lib. II, cap. 27, n, 44 (BAE 252, 44).
} 
La educación e instrucción de la juventud fue siempre para los jesuitas tarea de primer orden. En la misma dirección iban las preocupaciones de Solórzano. De ahí la enorme simpatía que cobró hacia ellos, cuyas obras gustaba de poner por modelo a los demás, «realmente - escribe- en todas partes se aventajan estos Padres en la enseñanza y amparo de los pobres indios, como de la demás juventud que tienen a su cargo» 228 .

En conclusión, se puede afirmar que se ha colocado, de una manera institucionalizada, por así decir, la piedra angular del gran edificio de la educación, imprescindible para crear una sociedad, justa, próspera y bien organizada.

Sólo desde la base de un sistema de educación bien ordenado se podía pensar en un paulatino y creciente autogobierno de los indios, tanto en el orden político-social como en el eclesiástico, hasta la total independencia Era la meta que había apuntado desde siempre la Escuela de Salamanca. El propio Solórzano menciona, entre otras, la cédula de 1549 en que se manda que «de los mismos indios se escojan unos como jueces pedáneos y regidores, alguaciles y escribanos y otros ministros de justicia que, a su modo y según sus costumbres, la administren entre ellos, determinen y compongan las causas de menor cuantía que se ofrecieren y tengan a su cargo los demás ministerios de sus pueblos y repartimientos» 229 .

Polo de Ondegardo, que lo puso en ejecución, dice que «experimentó maravillosos efectos, porque en muy breve tiempo se compusieron por esta vía más de dos mil pleitos entre los indios sin procesos mi alegatos ni juramentos o perjuros de testigos y otros embarazos que suelen tener y traer consigo» ${ }^{230}$. Acosta oyó directamente contar al mismo Ondegardo estos «maravillosos efectos» y los dejó a su vez referidos en la obra De procuranda indorum salute. El nombramiento de jueces e inspectores de entre los mismos indios obtuvo espectaculares resultados en la extirpación o disminución de una lacra social de enormes proporciones: las borracheras tanto públicas como privadas. Hasta el punto de que Acosta afirma haber escuchado del propio Ondegardo que «siendo corregidor del Cuzco, ciudad que es cabeza de las demás y otra Roma para los indios, en breve consiguió con esas medidas que no quedasen ni restos de embriaguez. Más aun, consiguió que los otros indios de las provincias más remotas, instruidos por los principales del Cuzco, imitasen tan buenos ejemplos de templanza y sobriedad. Pero por la negligencia y descuido de sus sucesores se malograron resultados tan importantes y se volvió a la antigua afición y costumbre de beber ${ }^{231}$.

228 O. c., lib. IV, cap. 16, n. 44 (BAE 253,

229 O. c., lib. II, cap. 27, n. 12 (BAE 252, 408).

230 Ibid.

231 José DE AcostA, De procuranda indorum salute, lib. III, cap. 22, n. 5 (CHP 23, 575). 
Tomás López Medel fue también decidido defensor de nombrar alcaldes y regidores entre los indios, con tal de que esta medida se aplique con prudencia política y con las debidas cautelas. De lo contrario, «sería dar el cuchillo al mochacho». Su opinión sobre este punto queda expresada con claridad en estas palabras: «Háseles de dar la jurisdicción por agora limitada, llevándolos poquito a poquito, según que fuesen entendiendo las cosas, dándoles un año poder para prender, otro año para conoscer de algunos delitos y castigallos, otro año para más, y así; y dándoles a entender que han de hacer sus residencias, porque hay grandes tiranía entre ellos» ${ }^{232}$. Es más, deberían designarse españoles honrados que visitasen muchas veces a estos alcaldes y regidores y se sentasen con ellos «a hacer y administrar justicia y les avezasen la autoridad que han de tener y cómo lo han de tener. Y así mesmo con los corregidores, que entrase con ellos en su casa de ayuntamiento y les enseñase el modo y manera que han de tener en ayuntarse, y cómo han de tratar las cosas de su república» ${ }^{233}$.

Todo un programa de pedagogía política que tiene como finalidad poner a los indios en condiciones de poderse gobernar a sí mismos. Años después Juan Zapata y Sandoval, a quien Solórzano cita elogiosamente con frecuencia, sacando las últimas consecuencias de esta tesis, formula el principio de «americanidad»: América para los americanos. «Bajo censura eclesiástica — dice Zapata - no temo afirmar ni tener por verdad que, de hallarse por lo demás dignos de tales cargos, se deben preferir los indios a los españoles en aquellos reinos en igualdad de circunstancias y sin peligro de escándalo... Por tanto, en la provisión de oficios y cargos civiles y eclesiásticos no se les ha de juzgar con derecho distinto al de los españoles, huéspedes y extranjeros... Advierto, sin embargo, ... que en todo esto se ha de entender, caso de que en el mismo lugar se encuentren individuos idóneos para desempeñar estos cargos y oficios» ${ }^{234}$. Y páginas más abajo da la razón: porque «si son iguales [a los españoles], ellos deben ser preferidos en su propio reino y patria a otros extranjeros. En igualdad de circunstancias son más merecedores que los otros por el conocimiento de la realidad y el amor a su pueblo» ${ }^{235}$.

De este principio se deduce como simple corolario que no hay razón ninguna para que sean excluidos del sacerdocio y marcados injustamente con la nota de incapacidad, porque esto sería incurrir en acepción de personas. Doctrina que Solórzano tiene «por certísima». Al igual que Zapata, condena la discutida incapacidad que algunos atribuyen a los criollos para ser ordenados sacerdotes, si se los halla idóneos: «no se puede dudar de que sean verdaderos españoles y

\footnotetext{
232 Tomás LóPEZ MEDEL, Informes y testimonios (CHP 28, 93-94).

233 Ibid.

234 Juan ZaPATA Y SANDOVAL, De iustitia distributiva et acceptione personarum ei oposita, II parte, cap. 11, nn. 14-16 (Vallisoleti, 1609, pp. 251-256); cfr. CHP 27, 71-73.

235 O. c., II parte, cap. 15, n. 11 (Vallisoleti, 1609, p. 296); cfr. CHP 27, 81.
}

Hispania Sacra, Missionalia hispanica, 58

117, enero-junio 2006, 263-327, ISSN: 0018-215-X 
como tales hayan de gozar de sus derechos, honras y privilegios y ser juzgados por ellos.

De este prejuicio, como indica Solórzano ${ }^{236}$, participó en alguna medida el propio Padre José de Acosta, cuando, sin excluirlos claramente, manifiesta sin ambages su grado de desconfianza hacia ellos. Reconoce, es verdad, que no hay que rechazarlos sin más, pues también entre los mestizos pueden hallarse personas muy dignas y capacitadas. «Pero aunque todo esto es verdad, sin embargo, la experiencia, maestra muy segura, demuestra de sobra que no podemos ni debemos descargar toda nuestra solicitud y cuidado confiados en la ayuda de los indígenas [criollos y mestizos] ni es conveniente encomendar tan gran empresa a hombres que son expertos en el idioma, pero cuyas costumbres no son tan a propósito. Porque de ordinario mantienen los resabios de la condición y costumbres de los indios, con cuya leche y trato se han criado» ${ }^{237}$. Pero bien advierte Solórzano que no «deben ser medidos por un rasero o pesados con una misma balanza todos los criollos que en ellas [las regiones americanas] nacen» ${ }^{238}$. Y testifica que en su tiempo y en el pasado «han sido insignes en armas y letras y, lo que más importa, en lo sólido de virtudes heróicas, ejemplares y prudenciales, de que me fuera fácil un copioso catálogo, si ya otros no lo hubieran tomado a su cargo» ${ }^{239}$.

No sólo los criollos, sino también los mestizos y mulatos (Solórzano silencia aquí a los indios mismos, expresamente mencionados en el principio elevado por Zapata) han de tenerse por ciudadanos con todos los derechos y han de admitirse a los cargos públicos e incluso ser ordenados sacerdotes, si en ellos concurren virtud y doctrina suficiente. El perfecto conocimiento de la lengua y costumbres indígenas sería sumamente provechoso para la evangelización de los indios. Y hacia eso cree Solórzano que miran algunas cédulas reales, como la de 1588, que permiten «ser ordenados los mestizos, y las mestizas recibidas por monjas, y admitidos a escribanías y regimientos» ${ }^{240}$. Sólo hay que indicar que «es necesario ir en ello con mucho tiento, porque vemos que los más salen de viciosas y depravadas costumbres y son los que más daño y vejaciones suelen hacer a los mismos indios» ${ }^{241}$.

Bien podemos decir que a esto apuntaba muy probablemente José de Acosta, cuando manifestaba su dejo de desconfianza en criollos, mestizos y mulatos. Por eso concluía que era necesario examinar «cuidadosamente la condición de esos hombres y probar por mucho tiempo sus costumbres, a fin de que cada

236 Juan SolóRZAno, Política indiana, lib. II, cap. 30, n. 9 (BAE 252, 443).

237 José DE ACOSTA, De procuranda indorum salute, lib. IV, cap. 8, n. 3 (CHP 24, 69).

238 Juan Solórzano, Política indiana, lib. II, cap. 30, n. 10 (BAE 252, 443).

239 O. c., lib. II, cap. 30 n. 14 (BAE 252, 444).

240 O. c., lib. II, cap. 30, n. 20 (BAE 252, 445).

241 O. c., lib. II, cap. 30, n. 26 (BAE 252, 446). 
cual vaya depurando la manera de pensar de una patria menos equilibrada y constante o más bien disoluta o frívola» ${ }^{242}$.

En la misma línea parecía moverse la tercera Congregación Provincial de los jesuitas de la Provincia del Perú, reunida en Lima el 3 de diciembre de 1582 bajo la presidencia del Provincial Padre Baltasar Piñas. En ella se determinó lo siguiente: «Cerca de los subiectos que en estas partes se hayan de recebir en la Compañía, se propuso: lo primero, si sería bien cerrar la puerta a mestizos; y a todos, nemine discrepante, pareció muy necesario que se les cierre del todo..., porque la experiencia ha mostrado a la larga no probar bien este género de gente; y las demás Religiones han abierto camino a la Compañía para esto con su exemplo... y el Rey tiene mandado no sean admitidos a Orden Sacro... De los criollos pareció a la Congregación que no se les podía del todo cerrar la puerta, antes se juzgó por necesario recibir algunos que parezcan aptos para la Compañía; pero que... se tuviese mucho delecto en recebirlos» ${ }^{243}$.

El III Concilio Provincial de Lima se contentará solamente en 1583 con senalar de manera generalizada la prohibición de admitir a las Órdenes sagradas a los indignos. Estas son sus palabras: «En el dar de las Órdenes menores y guardar los intervalos de tiempo señalados y principalmente en examinar con toda curiosidad la suficiencia de cualquiera que se haya de ordenar; y excluir a aquellos que no se hallaren suficientes, guarden los obispos enteramente los saludables decretos del Santo Concilio de Trento, pospuesto cualquiera otro humano respecto, de suerte que se muestren fieles despensadores de Dios y de su Iglesia. Y así no deben admitir al sacerdocio y ministerios sagrados a los que fueren indignos» ${ }^{244}$.

En resumen, conocedor directo de la realidad indiana, Solórzano se siente en la obligación de restablecer lo que él considera la verdad histórica de la colonización española y defender a la Corona española frente a las manipulaciones insidiosas y calumniosas propaladas por una leyenda negra que está naciendo y difundiéndose vertiginosamente por toda Europa. Esta circunstancia política que le ha tocado vivir está gravitando sobre el proceso de reflexión que pone en marcha para justificar la presencia de España en las Indias. Su preocupación afanosa por defender la posición española ante Europa le lleva a acumular títulos justificativos, cuya fuerza probativa no siempre aparece con la debida contundencia o incluso queda a veces en entredicho. Acepta, como es obvio, los que ya Vitoria consideró fundadamente títulos legítimos y se esfuerza por recuperar otros que el mismo Vitoria y con él toda la Escuela de Salamanca recha-

\footnotetext{
242 José DE AcostA, De procuranda indorum salute, lib. IV, cap. 8, n. 3 (CHP 24, 69-70).

243 Monumenta Historcia S. J., Monumenta Peruana, III 205-206, nn. 16-17.

244 Rubén Vargas Ugarte, Concilios Limenses (1551-1772). Tercer Concilio Provincial de Lima (1582-1583), cap. 33 (ed. VARGAS Ugarte, t. I, p. 337).
} 
zan por inválidos. En la medida en que esto ocurre se da un relativo distanciamiento de la doctrina sostenida por la Escuela salmantina.

Así, el estado de barbarie de los indios (aquellos que Acosta agrupa en la que él llama tercera clase) constituye para él un título legítimo de conquista. Lo constituyen también los pecados contra la naturaleza, incluyendo indistinta y confusamente en este concepto la idolatría e infidelidad, las blasfemias, las aberraciones sexuales, los sacrificios humanos, la antropofagia y la tiranía. Pero no tiene en cuenta una circunstancia que los maestros todos de la Escuela salmantina consideran esencial para clarificar y orientar debidamente la solución del problema, sean cualesquiera los pecados de que se trate; a saber, que en el pecado vaya o no vaya inclusa una injuria que se infiera al individuo o a la sociedad, porque no hay más causa justa de guerra que la injuria inferida.

Pero donde sorprendentemente salta la ruptura total con la Escuela es en el examen y fundamentación del décimo y último título justificativo de la ocupación de las Indias y que es, a su juicio, el más eficaz: la donación pontificia contenida en la Bula Inter caetera de Alejandro VI. Solórzano interpreta la Bula en un sentido rigurosamente literalista, otorgándole un amplísimo alcance, de acuerdo con las tesis que defienden la suprema potestad espiritual y temporal del Papa; es la línea marcada por el Requerimiento, tan cara a Sepúlveda. La donación pontificia habría de servirle también de base (juntamente con otros cinco títulos más) para justificar la retención o permanencia de España en Indias, una vez ocupadas éstas.

Solórzano enumera además y expone morosamente otros cinco títulos específicos que justifican, a su juicio, que los reyes de Castilla retengan las Indias y permanezcan en ellas: la seguridad de conciencia con que se retiene lo bien adquirido; la inmemorable prescripción de buena fe en la retención; la ayuda a los aliados en guerra justa; el libre consentimiento de los indios, y finalmente la imposibilidad práctica de una devolución de las Indias, dada la situación que se ha creado en el curso de los acontecimientos.

Pero Solórzano reconoce al mismo tiempo que se han cometido muchas crueldades, grandes atropellos y muy graves abusos de todo tipo por parte de determinadas personas o grupos, que han dado ocasión a las acusaciones de la Europa protestante contra España. Mas no por ello quedan comprometidos nuestros reyes, porque siempre — dice- han procurado lo mejor para los indios y han tomado con toda decisión su defensa mediante una cuidadosa selección de las personas que enviaban a las Indias con cargos de gobierno tanto en la esfera civil como en la eclesiástica. Así lo prueban también las innumerables instrucciones, ordenanzas y cédulas reales, que ininterrumpidamente han ido apareciendo desde los primeros tiempos, instando una y otra vez al buen trato, conservación e instrucción de los indios y castigando con severidad los excesos. 
En la Dedicatoria de su Política indiana al Rey Felipe IV transcribe Solórzano unas palabras de la cédula real (despachada el 3 de julio de 1627 para el Virrey y la Audiencia de México) que «vale por muchas para defensa y satisfacción de las calumnias con que en esta parte quieren mancharnos los extranjeros». Las palabras que el Rey «puso de su real mano y letra» son las siguientes: «Quiero que me deis satisfacción a mí y al mundo del modo de tratar esos mis vasallos; y de no hacerlo y de que en respuesta no vea yo executados exemplares castigos en lo que hubieren excedido en esta parte, me daré por deservido. $\mathrm{Y}$ asegúroos que, aunque no lo remediéis, lo tengo de remediar y mandaros hacer gran cargo de las más leves omisiones en esto, por ser contra Dios y contra mí y en total destruición de esos reinos, cuyos naturales estimo y quiero sean tratados como lo merecen vasallos que tanto sirven a la monarquía y tanto la han engrandecido e ilustrado» 245 .

Los excesos tuvieron lugar sobre todo en los comienzos del descubrimiento y ocupación, cuando, a falta todavía de una sociedad mínimamente estable, se hacía prácticamente imposible el control. Contribuyeron así mismo al lamentable fenómeno de la despoblación, cuya causa principal, sin embargo, no fueron las guerras sino las terribles epidemias, los terremotos, los trabajos forzados y los propios vicios de los naturales. Esto no impide que Solórzano reconozca sinceramente la responsabilidad que atañe a los españoles, en mayor o menor grado, por las atrocidades que se perpetraron en las Indias. Aduce, sin embargo, como atenuantes (a una con Acosta) la distancia de la metrópoli y el salvajismo y barbarie de los indios que les inducían a excederse en los castigos.

En el volumen II de De Indiarum iure y en su Política indiana Solórzano se esfuerza por demostrar que, a pesar de las desviaciones, errores y abusos que se hayan podido cometer (propios de toda obra humana), España había logrado de hecho poner en pie y organizar en el ámbito civil y eclesiástico una nueva sociedad hispano-indiana sobre bases de justicia y respeto.

En contraste con esta obra colonizadora y evangelizadora de España, Solórzano quiere desenmascarar la hipocresía de los que «nos calumnian y nos muerden», los cuales silencian «las totales destrucciones de las islas y otras tierras que tirana e injustamente las han ocupado y saqueado; y otras que han poblado sirviéndose de ellos con gran crueldad e insaciable codicia hasta consumirlos, sin que puedan mostrar que hayan tenido cuidado alguno de doctrinarlos, sino antes pervertirlos con sus execrables errores, ni se halle que hayan fundado iglesia ni erigido obispado, siendo casi innumerables las que se hallan por nuestra parte» 246 .

245 Juan Solórzano, Política indiana. Dedicatoria, n. 17 (BAE 252, 10).

246 O. c., lib. I, cap. 12, nn. 33-34 (BAE 252, 127). 
Una vez expuestos los títulos legítimos que justificaban, a su juicio, tanto la conquista como la retención de las Indias y permanencia de España en ellas, Solórzano da el último paso mostrando que la actual administración y gobernación de las Indias se ajustan plenamente a derecho. Para ello somete a riguroso examen las principales instituciones religioso-sociales sobre las que debe estar fundamentado el funcionamiento de toda república bien organizada. Porque bien podría ocurrir que una injusta posterior administración hiciera así mismo injusta la permanencia de España en aquellas regiones. Por eso se esfuerza Solórzano por mostrar morosa y detalladamente el correcto funcionamiento sobre todo de las siguientes instituciones: las encomiendas (institución especialmente controvertida), el tema de los tributos, los llamados «servicios personales» y el importante y gravísimo problema de la educación y promoción de los indios. 